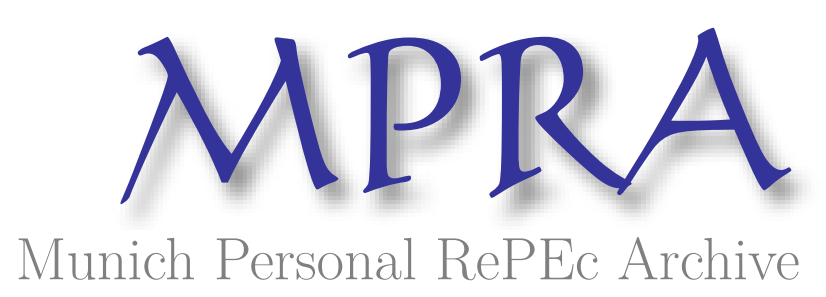

\title{
ICT Diffusion, Foreign Direct Investment and Inclusive Growth in Sub-Saharan Africa
}

Ofori, Isaac Kwesi and Asongu, Simplice A.

University of Insubria, African Governance and Development Institute

13 May 2021

Online at https://mpra.ub.uni-muenchen.de/107757/

MPRA Paper No. 107757, posted 26 May 2021 01:21 UTC 


\title{
$\underline{\text { A G D I Working Paper }}$
}

\author{
$\mathrm{WP} / 21 / 029$
}

\section{ICT Diffusion, Foreign Direct Investment and Inclusive Growth in Sub- Saharan Africa}

\author{
Isaac K. Ofori \\ (Corresponding author) \\ Department of Economics, \\ University of Insubria, \\ Via Monte Generoso, 71, 21100, VA, Varese, Italy. \\ E-mails: isaac.ofori1@ucc.edu.gh; \\ ikofori@uninsubria.it; \\ $+393207953101$

\section{Simplice A. Asongu} \\ African Governance and Development Institute, \\ P.O Box 8413, Yaoundé, Cameroon \\ E-mails: asongusimplice@yahoo.com; \\ asongus@afridev.org
}




\title{
Research Department
}

\section{ICT Diffusion, Foreign Direct Investment and Inclusive Growth in Sub-Saharan Africa}

\author{
Isaac K. Ofori \& Simplice A. Asongu
}

May 2021

\begin{abstract}
This study examines the joint effects of ICT diffusion (composed of access, usage and skills), and foreign direct investment (FDI) on inclusive growth in sub-Saharan Africa (SSA). The study draws on data from the World Bank's World Development Indicators, and the Global Consumption and Income Project for the period 1980-2019 for the analysis. The study provides evidence robust to several specifications from ordinary least squares and dynamic system GMM estimation techniques to show that: (1) FDI and ICT diffusion and corresponding components (ICT access, usage, skills) induce inclusive growth in SSA; (2) compared to its direct effect, FDI is remarkable in fostering shared growth in SSA in the presence of greater ICT diffusion, and (3) compared to ICT access and usage, ICT skills are more effective in driving inclusive growth in SSA. Overall FDI modulates ICT dynamics to engender positive synergy effects on inclusive growth. Policy recommendations are provided in line with the implementation of the African Continental Free Trade Area (AfCFTA) Agreement and the projected rise in FDI in SSA from 2022.
\end{abstract}

Keywords: FDI; ICT Access; ICT Diffusion; ICT Skills; ICT Usage; Inclusive Growth; subSaharan Africa

JEL Classification: E23; F21; F30; L96; O55 


\subsection{Introduction}

The call for sub-Saharan African (SSA) countries to pursue inclusive growth has intensified following the coming into force of the African Continental Free Trade Area (AfCFTA) Agreement and the Coronavirus pandemic. The latter has indeed laid bare the porous growth trajectories of the region in recent times and has been cited as one of the reasons SSAplummeted into a record 3.2 per cent contraction in economic activity in 2020 (Brown et al. 2020; IMF 2020a; World Bank 2020a). The World Bank (2020b), ILO (2020a) and OECD (2020a) in particular, report of substantial setbacks to Sustainable Development Goals 1, 8 and 10 made over the past few years. The socioeconomic outlook of the region is not encouraging either - a further 25-35 million people are expected to slip into the extreme poverty bracket in 2021, down from 110 - 125 in 2020 (World Bank 2020b) while income inequality is also expected to rise due to job losses, food price shocks, slow recovery of informal activities and low social protection (Kovacevic and Jahic 2020; ILO 2020b; World Bank 2020b).The seriousness of these welfare setbacks and projections are seen in Pickett and Wilkinson (2015) who argue that poverty and inequality have pernicious implications for the quality of life, health, education, social protection efforts, and mortality. Going forward, fostering sustainable and durable growth in SSA is not only imperative for addressing human resource wastage, social tensions and political instability, but also offers the surest way of lessening the impacts of future socioeconomic shocks.

Despite SSA's obvious challenges regarding resource mobilisation, gender equality, infrastructure and social equity, institutions are two key developments in the region that offer glimmers of hope - the rise in information and communication technology(ICT) diffusion, and foreign direct investment (FDI). In a region where there are unmet gaps for infrastructure development, and the population is youthful and innovative, ICTs and FDI can be targeted to foster shared prosperity. This is where this study contributes to the current discourse. If these welfare setbacks due to COVID-19 can be addressed and usher SSA into a path of resilient shared growth, ICT diffusion and FDI should be looked at carefully. First, even before the coming into force of the AfCFTA, SSA was a major recipient of FDI from the European Union and Asia (UNCTAD 2019). The optimism with FDI in driving inclusive growth in SSA is evident in the projected inflows ${ }^{1}$ into the extractive industries of precious metals and hydrocarbons, manufacturing, aviation, telecommunication, banking, and construction in line with the AfCFTA (UNCTAD 2020). Particularly, the elimination/reduction in tariffs and the

\footnotetext{
${ }^{1}$ FDI inflow into SSA is set to rebound in 2022 according to the UNCTAD (2020)
} 
huge market size of at least 1.2 billion people can incentivize market-seeking FDI, providing opportunities for employment, agricultural-sector revival and increased global value chain participation.If there were any doubts about the inclusive-power of ICT diffusion, the pandemic hobbled it all. Indeed, the usefulness of ICTs deepened in the heat of the COVID19 pandemic as it facilitated smooth settlements of bills, ordering of consumables, digital banking, e-learning, preservation of jobs, entertainment, e-Governance, and access to general information.

Inter alia, ICT scan also induce FDI inflow especially into the financial sector, manufacturing and telecommunication sectors due to its power in reducing managerial risk, production and transaction costs while offering limitless market coverage, and innovation transfer (Salahuddin and Gow 2016; Shamim 2007;Mody1997).Despite the possible modulating effect of FDI on the link between ICTs and inclusive growth, the gap in the literature particularly on SSA is that rigorous empirical works exploring such pathway effect is hard to find. Additionally, the question as to which component of ICT diffusion (i.e., access, usage or skills) is strongest in driving inclusive growth in the SSA remains unanswered. The closest studies we sighted are Asongu and Odhiambo (2020) and Adeleye et al.(2020). While former explores the joint effects of FDI and ICTs on economic growth in SSA, the latter pays attention to trade openness (i.e., the sum of export and import as a share of GDP) and ICTs on inclusive growth. Further, a plethora of the empirical works also estimate the direct effects of FDI/ICT diffusion on economic growth/inclusive growth without paying attention to the joint effects (see., Ejemeyovwi and Osabuohien2018; Tella and Alimi2016; Johnson 2016; Adeleye and Eboagu 2019; Albiman and Sulong2017). As Berg and Ostry (2011) reckon, it is 'mistake' to limit the analysis of shared growth to economic growth as it downplays the relevance of social equity in economic development. This study fills the attendant gaps and adds to the literature on two counts - first, by exploring the direct effects of ICT diffusion and FDI on inclusive growth in SSA, and second, by investigating the joint effect of ICT diffusion and FDIon inclusive growth in SSA.

The rest of the paper is organised as follows: the next section presents the theoretical link between ICT, FDI and inclusive growth. Section 3 outlines the methods used for the paper. We present our results and discussion in section 4. A conclusion with policy recommendations is provided in section 5 . 


\subsection{The theoretical link between FDI, ICT diffusion and inclusive growth}

The theoretical link between trade and shared growth stem from the argument that by specializing in cross-border production activities in which they have abundant factors, countries can put natural resources to use to the benefit of the masses (Stolper-Samuelson 1941; Ohlin 1933; Samuelson 1939). A related theory is the modernization theory, which suggests that FDI can contribute to the development of recipient countries through employment creation, technological transfer, and economic linkage (Solomon 2011; Li and Liu 2005; Durham 2004; Bengoa and Sanchez-Robles 2003). The theoretical link between ICT diffusion and inclusive growth also rests on the Sustainable Livelihoods Approach (SLA) framework (see, Kwan and Chiu 2015). The SLA framework takes its roots from Sen's notion ${ }^{2}$ of the set of 'functionings' and 'doings' in people's capabilities (Sen, 1999). The SLA denotes the different linkages between livelihood assets, institutions, policies, and people's livelihood outcomes (Messer and Townsley 2003). The framework thus indicates that if economic agents have access to assets like ICTs; these provide a level playing field by enabling the masses create/take advantage of opportunities. It is in the context of this and the flexibility of the SLA concept in analysing shared growth that ICTs are incorporated into the framework (see, Duncombe 2006). On the basis of the foregoing theoretical undertones, we test two main hypotheses- (1) whether ICT diffusion and FDI induce inclusive growth in SSA, and (2) whether there is a joint effect of ICT diffusion and FDI on inclusive growth in SSA. To inform policy about which component of ICT diffusion is more effective in driving inclusive growth directly, and indirectly contingent on FDI, ICT access, usage and skills are also considered in the estimation.

\subsection{FDI-inclusive growth nexus}

Despite evidence that FDI can induce income inequality in the developing world (Mihalache$\mathrm{O}$ and $\mathrm{Li}, 2011$ ), some studies also argue that FDI can drive shared growth through job creation, revival of industrial capacity of recipient countries, and corporate social responsibility (Kotler and Lee 2005). Further, in a setting where infrastructure development is growing, institutional frameworks are being developed (African Development Bank 2010), natural resources abound, and the population is youthful, FDI can possibly be a game changer in spurring shared growth in SSA. Even before the COVID-19 pandemic, FDI inflow into

\footnotetext{
${ }^{2}$ Sen argues that matters in people's well-being is what they are capable of being or doing with the goods to which they have access.
} 
SSA as we show in Figure 1 compared well to regions like the South Asia and the Middle East and North Africa (MENA).

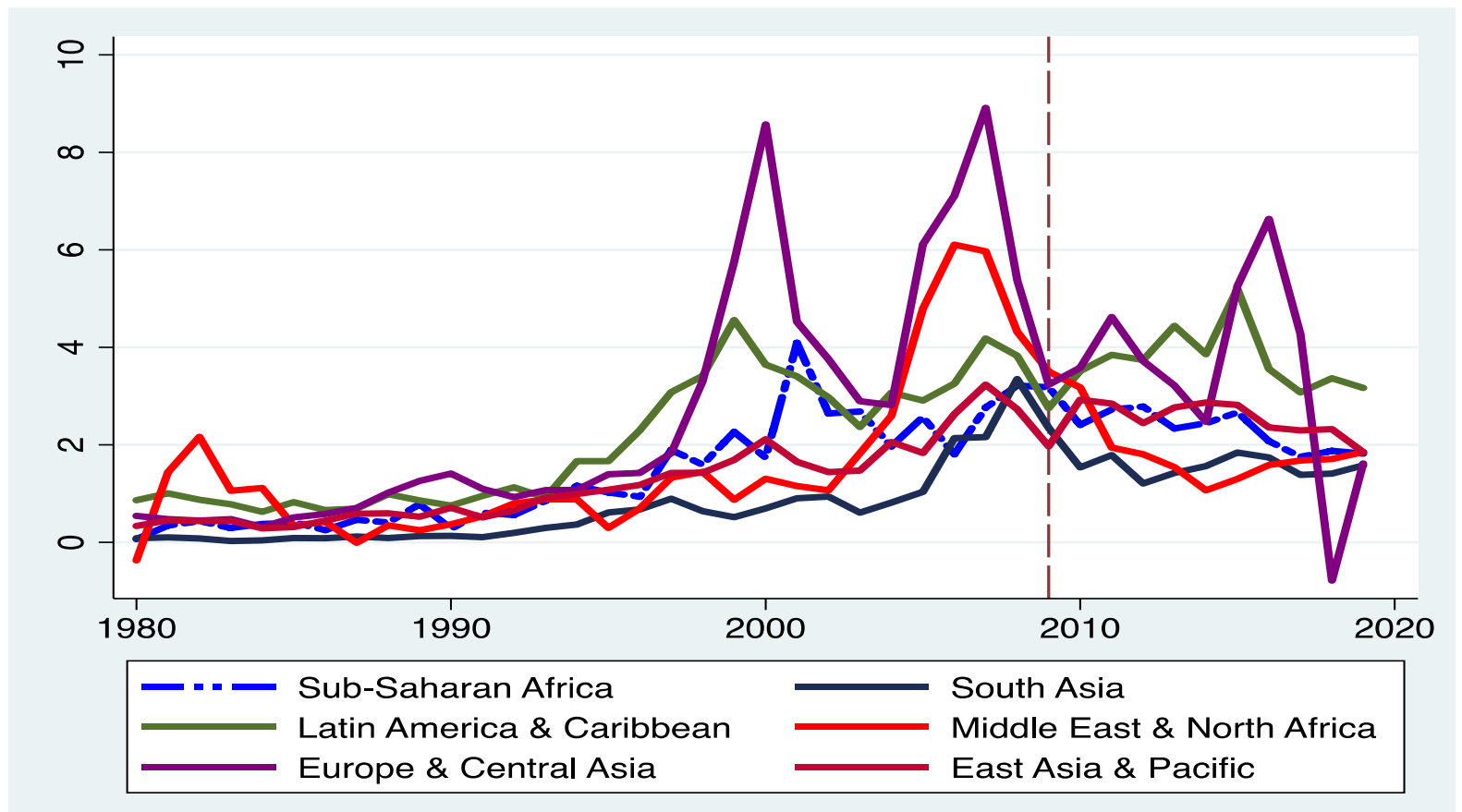

Figure 1: Trend of FDI Inflow (\%GDP) Across Regions, 1980 - 2020

Particularly, despite FDI inflow into regions such as South Asia, MENA and European and Central Asia plummeting continuously after the 2008/2009 global financial meltdown, FDI inflow into SSA rebounded quickly after the crisis (UNCTAD 2013). Despite declining by about 10 per cent in 2019 and 23 per cent in 2020 due to the geopolitical concerns and COVID-19, FDI inflows into the region are expected to rebound in 2022 following the AfCFTA and the expected finalization of negotiations on the associated investment protocol. Indeed, there is within-country variability in FDI inflow into SSA as we show in Figure A.1, with countries such as Nigeria, South Africa, Ghana, Mozambique, Angola and Gabon ranking favourably. This development means that with appropriate institutions and investment strategies, the inclusive growth-inducing effects of FDI can possibly be harnessed.

\subsection{ICT diffusion and inclusive growth in Sub-Saharan Africa}

The world is ever-changing in line with the current digital and information age. As Castells (1999) puts it, the lack of ICTsin itself is a form of social deprivation, and is akin to lack of access to electricity in the 'industrial age'. The skepticism surrounding the growth-inducing 
power of ICT in the developing world centres on affordability, adaptability, poor infrastructure, and possible inequality- and unemployment-inducing effects (see e.g., Chowdhury 2000; Bedia 1999). However, researchers such as Asongu and Le Roux (2017), Grace and Kenny (2003), and Brown (2001) have hobbled such arguments, arguing that ICT diffusion offers a good medium to leapfrog development, and enhance inclusiveness ${ }^{3}$. Despite the momentous rise inICT access, skills, and usagein the last three decades in SSA as we show in Figure 3, as compared to other regions, there is still exist substantial unmet gaps which can be harnessed to boost shared growth (Humbani and Wiese 2018; Afutu-Kotey et al.2017; Asongu 2013)
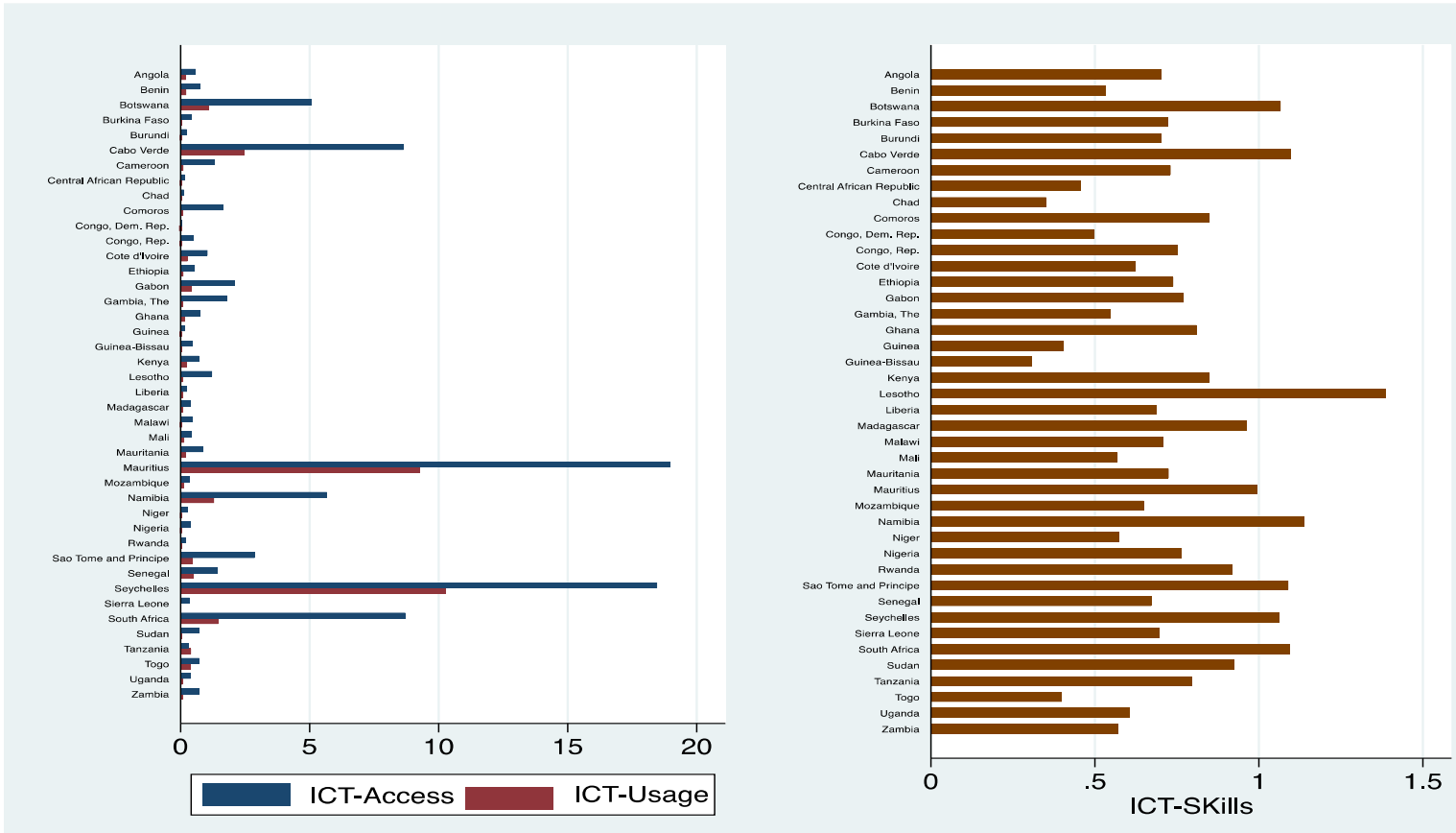

Figure 2: Average Within-Country ICT Access, Usage and Skills In SSA, 1980 - 2020

The growing ICT access, skills and usage, markedly, in countries like Gabon, Mauritius, South Africa, Cape Verde, Namibia, Seychelles, Nigeria, and Ghana can offer limitless shared opportunities - first, by creating green wealth through innovationand access to greater markets like the one offered by the AfCFTA; second, by inducing FDI inflow; third, by enhancing access to education, information and knowledge transfers; and fourth, by facilitating relationship, network building, e-Governance, accountability, and social inclusion (see, Donou-Adonsou 2019; Mengesha and Garfield, 2019; Palvia et al. 2018; Tchamyou 2017; Asongu and Odhiambo 2019a; Mahmood et al. 2019; Rondović et al. 2019; Sassi and

\footnotetext{
${ }^{3}$ Such is the example of the Asia Pacific region, where countries such as Hong Kong, Taiwan, Singapore, and South Korea leapfrogged development through ICT diffusion.
} 
Goaied 2013). In relation to the growing ICT diffusion in the SSA is the springing up of innovation/technological hubs ${ }^{4}$ and industrial parks noticeably, in countries such as South Africa, Nigeria, Kenya, and Ghana (see, Figure A.2), connecting young programmers, designers, entrepreneurs, and investors for the cultivation and nurturing of ideas. In fact, information gleaned from GSM Association shows the momentous rise in tech-hubs in SSA, from 314 in 2016, to 442 in 2017, and 643 in 2019. Plausibly, therefore, if prioritized with ICT access, skills and usage, FDI can yield the inclusive growth dividends as the visual relationships we provide in Figure 3 indicate.
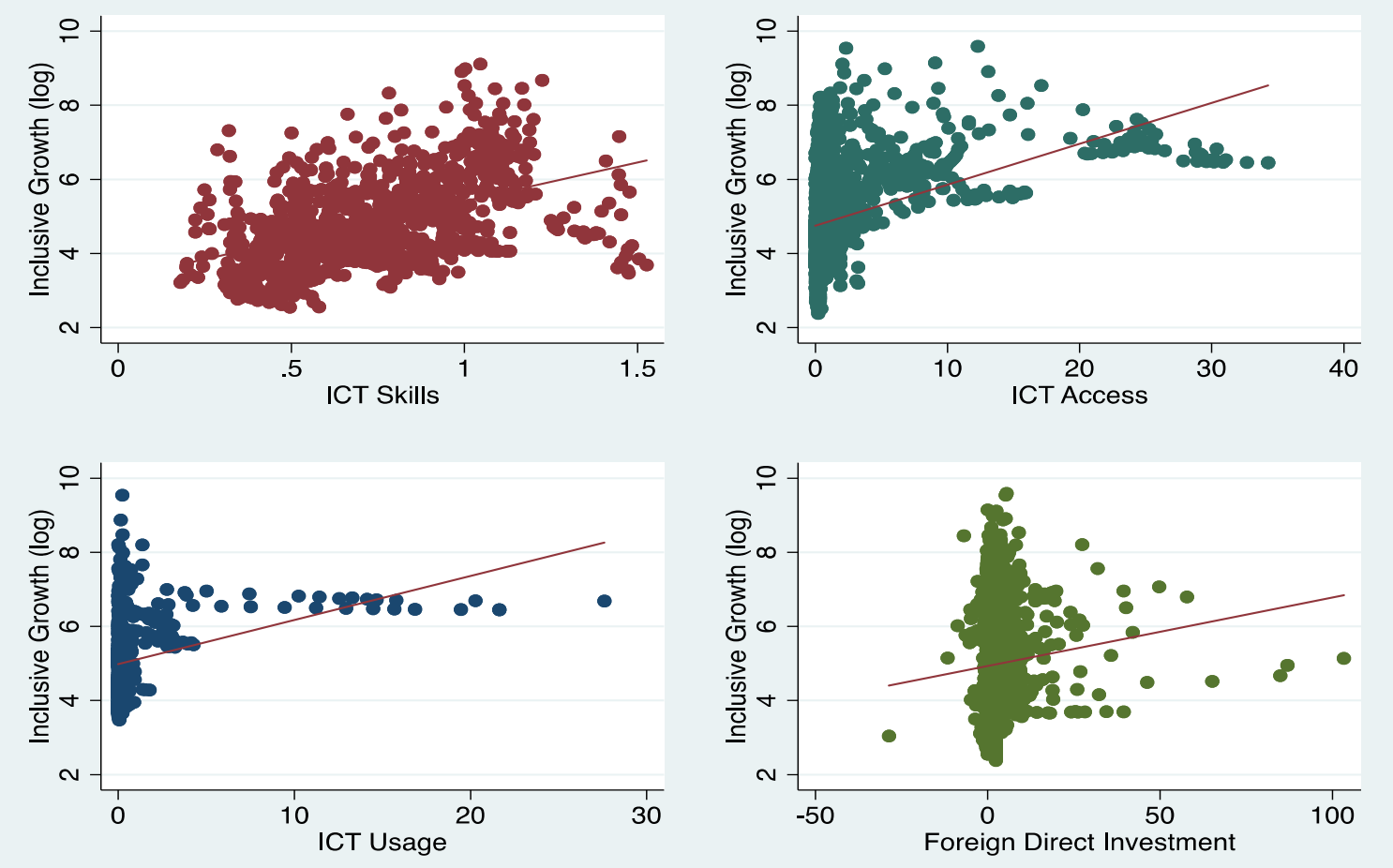

Figure 3: FDI, ICT Diffusion - Inclusive Growth Nexus

\subsection{Definition and drivers of inclusive growth: A brief review}

Achievingeconomic growth is one thing while achievingshared prosperity is another. In SSA, the literature shows that much attention has not been paid to inclusive growth (See, Greenwald and Stiglitz 2013). Despite encouraging growth strides in countries like Namibia, South Africa, Gabon, Botswana, Angola, Ghana, and Seychelles over the last three decades,

\footnotetext{
${ }^{4}$ Major tech-hubs in SSA are the SmartXchange, RLABS, and JoziHub of South Africa; Kinu of Tanzania; iSPACE of Ghana; xHub, IHub, Swahili Box, eMOBILIS, and Afrinovator of Kenya; and Co-creation Hub, Wennovation Hub, Focus Hub of Nigeria.
} 
Figure 4 shows that such growth trajectories have not been inclusive ${ }^{5}$. On the one hand, inclusive growth is seen in absolute terms as growth that is largely beneficial to the poor and marginalized (Ravallion and Chen 2004), and in another breath as growth in incomes of the poor compared to the overall population (IMF 2011). Ali and Son (2007), Berg and Ostry (2011) and Asian Development Bank (2013) also see inclusive growth as growth trajectories that increase social opportunities in terms of incomes, employment, human capital development, and social safety nets that enhance the capacity of the masses to contribute to national development.

On the empirical front, Anand et al. (2013) provide evidence to show that globalisation, foreign direct investment, and trade openness induce inclusive growth. Studies such as Paramasivan et al. (2014), Estache et al. (2013) and Lustig et al. (2012) also argue that while productivity and employment growth are crucial, interventions in human capital development, gender equality, and social safety nets are equally significant in fostering shared prosperity. Lustig et al. (2012) in particular show that the recent welfare gains in the LAC is at the backdrop of improved social protection efforts. A similar argument is found in World Bank (2013, 2009) and Acemoglu and Robinson (2012) who argue that inclusive growth rests on stronger institutions, structures, and policies aimed at building the capabilities of the marginalised. The IMF and World Bank (2020), Calderón and Servén (2014)and the Asian Development Bank (2013) also reckon that while government expenditure in education and health is needed to foster equitable growth,infrastructural development and irrigation are equally relevant for building a good commercial and investor climate for the private sectorto thrive.

\subsection{Data and methodology.}

\subsection{Data}

The dataset underpinning this study is entirely macro and spans $1980-2019$ for 42 SSA countries $^{6}$. Data on inclusive growth is not directly accessible in databases and as such is generated. Inclusive growth is calculated based on a utilitarian social welfare function drawn from consumer choice literature, where shared growth depends on two factors: (i) income

\footnotetext{
${ }^{5}$ While GDP per capita of these countries exceeds US\$5000, in terms of inclusive growth, no country achieves US\$2500.

${ }^{6}$ Angola, Benin, Botswana, Burkina Faso, Burundi, Cabo Verde, Cameroon, Central African Republic, Chad, Comoros, Congo, DR., Congo, Cote d'Ivoire, Ethiopia, Gabon, The Gambia, Guinea, Ghana, Guinea Bissau, Kenya, Lesotho, Liberia, Madagascar, Malawi, Mali, Mauritania, Mauritius, Mozambique, Namibia, Niger, Nigeria, Rwanda, Sao Tome and Principe, Senegal, Seychelles, Sierra Leone, Sudan, South Africa, Tanzania, Togo, Uganda, Zambia.
} 
growth (proxied by GDP per capita); and (ii) income distribution (proxied by Gini index) (Anand et al. 2013) (See calculation as Supplementary Material in the Appendix Section). Both GDP per capita and Gini index are sourced from the World Bank's World Development Indicators (World Bank 2021), with missing observations in the latter filled using data from the Global Consumption and Income Project (see, Lahoti et al. 2016). In Section 4.4, our estimates on inclusive growth are robustly checked with another measure of shared growth proposed by the Asian Development Bank (2013). The variables of interest are ICT diffusion (including its key sub-components of access, usage and skills) and FDI. FDI is captured as the net inflow as a percentage of GDP while ICT diffusion is an index calculated via the Principal Component Analysis (PCA). Additionally, ICT access, usage and skills are captured respectively as fixed telephone subscription, fixed broadband subscription, and secondary school education gender parity. A number of variables are also controlled to take into consideration the implications of the economic structure of the SSA, macroeconomic management, institutions and finance in shared growth (Tchamyou 2020, 2021). In specifics, human capital, vulnerable employment, inflation and financial access/deepening are considered. Financial deepening is an index sourced from the IMF's financial development index (Svirydzenka 2016) while inflation and human capital are measured by the consumer price index and human capital index, respectively. Moreover, social protection is also measured as the country policy and institutional assessment score. Data on all other controls and the ICT variables are drawn from the World Development Indicators. The description of the variables is provided in Table 1 while their pairwise correlations are reported in Table A.1

Table 1: Variable description and sources

\begin{tabular}{|c|c|c|}
\hline Variables & Description & Source \\
\hline Inclusive Growth & Income growth and distribution & Author \\
\hline Inclusive Growth Index & Inclusive growth index calculated via PCA & Author \\
\hline Social protection & $\begin{array}{l}\text { Coverage of social protection and labor programs (\% of } \\
\text { population) }\end{array}$ & WDI \\
\hline Foreign Direct Investment & Net foreign direct inflow (\%GDP) & WDI \\
\hline Gini index & Gini income inequality indicator & WDI; GCIP \\
\hline Financial access & $\begin{array}{l}\text { Financial institutions access capturing the access of } \\
\text { people to financial institutions }\end{array}$ & Findex \\
\hline GDP per capita & Real GDP divided by population & WDI \\
\hline Inflation & Consumer price index $(2010=100)$ & WDI \\
\hline Vulnerable Employment & $\begin{array}{l}\text { Total contributing family and own-account workers as a } \\
\text { share of total employment }\end{array}$ & WDI \\
\hline ICT Diffusion & ICT Diffusion Index calculated via PCA & Author \\
\hline ICT Access & Fixed telephone subscriptions (per 100 people) & WDI \\
\hline ICT Usage & Fixed broadband subscriptions (per 100 people) & WDI \\
\hline ICT Skills & Gross secondary school enrolment gender parity index & WDI \\
\hline
\end{tabular}

Note: WDI is world development indicators; Findex is IMF's Financial Development Index; GCIP is 
Global Consumption and Income Project

Source: Authors' construct, 2021

\subsection{Theoretical and estimation strategy}

The theoretical foundation of this paper rests on the modernization theory (see, Solomon2011; Li and Liu 2005; Durham 2004) and the SLA framework (see, Kwan and Chiu 2015), which respectively position FDI and ICT diffusion in shared growth. The empirical strategy is thus the exploration of the joint effects of ICT diffusion in general, ICT access, usage, skills and FDI on inclusive growth. The empirical rigor of this paper begins with the specification of bivariate models, testing the relationship between FDI, ICT diffusion, ICT access, usage, skills and inclusive growth. Next, we specify a baseline model to explore the effects of the control variables on inclusive growth. Finally, in line with the hypothesized joint effects ${ }^{7}$ of ICT diffusion and FDI on inclusive growth, both variables as well as their interaction terms are introduced in the model. The bivariate models ${ }^{8}$ are specified as follows:

$$
\begin{aligned}
& \ln \left(\text { igrowth }_{i t}\right)=\lambda_{0}+\beta_{1} \ln \left(f d i_{i t}\right) \\
& \ln \left(\text { igrowth }_{i t}\right)=\lambda_{0}+\beta_{1} \ln \left(\text { ictdif }_{i t}\right)
\end{aligned}
$$

The baseline model is specified in (3) as:

$$
\begin{aligned}
& \ln \left(\text { igrowth }_{i t}\right)=\lambda_{0}+\beta_{1} \ln \left(\text { igrowth }_{i t-1}\right)+\beta_{2} \ln \left(\text { hci }_{i t}\right)+\beta_{3} \ln \left(\text { inf }_{i t}\right)+\beta_{4} \ln \left(\text { vul }_{i t}\right)+ \\
& \beta_{5} \ln \left(\text { findep }_{i t}\right)+\beta_{6} \ln \left(\operatorname{soc}_{i t}\right)+\mu_{i}+\mu_{t}+\epsilon_{i t}
\end{aligned}
$$

To capture the joint effect of FDI and ICT diffusion, equation (3) is modified to obtained (4)

$$
\begin{aligned}
& \ln \left(\text { igrowth }_{i t}\right)=\lambda_{0}+\beta_{1} \ln \left(\text { igrowth }_{i t-1}\right)+\beta_{2} \ln \left(\text { hci }_{i t}\right)+\beta_{3} \ln \left(\text { inf }_{i t}\right)+\beta_{4} \ln \left(\text { vul }_{i t}\right)+ \\
& \beta_{5} \ln \left(\text { findep }_{i t}\right)+\beta_{6} \ln \left(\text { soc }_{i t}\right)+\beta_{7} \ln \left(f d i_{i t}\right)+\beta_{8} \ln \left(\text { ictdif }_{i t}\right)+\beta_{9} \ln \left(f d i_{i t} \times \text { ictdif }_{i t}\right)+ \\
& \mu_{i}+\mu_{t}+\epsilon_{i t}
\end{aligned}
$$

Where igrowth denotes inclusive growth; $\boldsymbol{h c i}$ is human capital index; vul is vulnerable employment; inf is inflation; findep is financial deepening; soc is social protection score while $\boldsymbol{f d i}$ denotes foreign direct investment. Also, fdi $\times$ ictdif is the interaction term for foreign direct investment and ICT diffusion; $i$ is country; $t$ is time; $l n$ is the natural logarithm; $\mu_{i}$ is the country-specific effects; and $\epsilon_{i t}$ is the idiosyncratic error term. While we expect the lag of inclusive growth, human capital, FDI, social protection and financial deepening to foster shared prosperity, inflation and vulnerable employment are expected to suppress inclusive

\footnotetext{
${ }^{7}$ It is imperative to note that joint effects for the sub-components of ICT diffusion- ICT access, ICT usage and ICT skills and FDI are also investigated.

${ }^{8}$ For brevity, the bivariate models for the subcomponents if ICT diffusion are not presented in this section.
} 
growth efforts. There is a suspicion of endogeneity due to the introduction of the lag of inclusive growth. The endogeneity problem arises since igrowth $h_{i t-1}$ depends on $\varepsilon_{i t-1}$, which is a function of the country-specific effect $\epsilon_{i}$. To the extent that endogeneity can bias our estimates, we address it by applying the system GMM technique ${ }^{9}$ put forward by Arellano and Bover (1995). The net effects from the interaction terms of ICT diffusion and FDI on inclusive growth from equations (4) is expressed as:

$\frac{\partial \ln (\text { igrowth })}{\partial \ln (\text { ictdif })}=\delta_{8}+\delta_{9} \overline{\ln (f d l)}$

where $\overline{f d l}$ is the average FDI inflow into SSA over the study period.It is imperative to note that in evaluating the reliability of the estimates, several post estimation tests are conducted to test whether-(i) there is evidence of second-order serial correlation in the residuals or not; (ii) whether our instruments are valid or exogenous; (iii), whether the interaction terms are significant, and(iv)the overall model is significant.

\subsection{Results and discussion}

\subsection{Summary statistics}

Summary statistics of the variables are presented in Table 2. The data shows that growth in SSA is not inclusive. Table 2 shows an average inclusive growth value of US\$349.8, compared to the average GDP per capita value of US $\$ 3834.5$ over the study period.

Table 2: Summary statistics

\begin{tabular}{|c|c|c|c|c|c|}
\hline Variables & Obs & Mean & Std. Dev. & Minimum & Maximum \\
\hline Inclusive Growth & 1680 & 349.778 & 844.604 & 10.834 & 14647.05 \\
\hline Inclusive Growth Index & 1680 & 0.01 & 1 & -1.901 & 2.855 \\
\hline GDP Per Capita & 1680 & 3834.477 & 4416.887 & 436.72 & 29223.465 \\
\hline Gini Index & 1680 & 53.25 & 19.83 & 0 & 86.832 \\
\hline Foreign Direct Investment & 1680 & 2.939 & 6.457 & -28.624 & 103.337 \\
\hline Vulnerable Employment & 1680 & 71.022 & 22.858 & 8.826 & 94.759 \\
\hline Inflation & 1680 & 59.364 & 46.513 & 0 & 410.94 \\
\hline Human Capital Index & 1680 & .395 & .072 & 0 & .678 \\
\hline ICT Diffusion Index & 1680 & 0.01 & 1 & -1.712 & 2.563 \\
\hline ICT Access & 1676 & 2.178 & 4.855 & 0 & 34.273 \\
\hline ICT Usage & 1676 & .836 & 2.852 & 0 & 27.603 \\
\hline ICT Skills & 1680 & .772 & .274 & .18 & 1.527 \\
\hline Financial Deepening & 1680 & .077 & .129 & 0 & .88 \\
\hline Social Protection & 1680 & 21.545 & 15.002 & 0 & 96.405 \\
\hline
\end{tabular}

Note: Obs is Observation $(N \times T)$; Std. Dev. is Standard deviation

Source: Authors' construct, 2021

\footnotetext{
${ }^{9}$ In estimating our system GMM models, the instruments are the lags of the regressors.
} 
Indeed, Figure A.3 makes clear the less-inclusive growth trajectories of the region in the past four decades. It is evident from Figure A.3 that non-inclusive growth is marked in countries like Namibia, South Africa, Ghana, Gabon and Seychelles. On the variables of interest, the data shows an average FDI of 2.93 per cent, and ICT diffusion index of 0.001 . For the subcomponents of access, usage, and skills, the average values are 2.17, 0.83, and 0.77, respectively. For variables such as inflation, human capital index, vulnerable employment, and financial deepening, the mean values are 59.36, 0.39, 71.02 and 0.08, respectively. The average vulnerable employment and inflation give an indication of a high informal real sector and macroeconomic instability in the region.

\subsection{Bivariate results on the effects of FDI and ICT diffusion on inclusive growth}

The bivariate results on the effects of ICT diffusion, access, usage, skills, and FDI are presented in Table 3. The results show that all the variables exert a positive influence on inclusive growth in SSA. The relationships are strong at the 1 per cent level of significance, with the effect of ICT skills being the most remarkable.

Table 3: Bivariate results on the effects of FDI and ICT diffusion on inclusive growth (Dependent variable: Inclusive growth)

\begin{tabular}{|c|c|c|c|c|c|}
\hline Variables & (1) & $(2)$ & (3) & (4) & $(5)$ \\
\hline Foreign Direct Investment & $\begin{array}{c}0.0185^{* * *} * \\
(0.0045)\end{array}$ & & & & \\
\hline ICT Diffusion & & $\begin{array}{c}0.5918 * * * \\
(0.0503)\end{array}$ & & & \\
\hline ICT Access & & & $\begin{array}{c}0.1105 * * * \\
(0.0054)\end{array}$ & & \\
\hline ICT Usage & & & & $\begin{array}{c}0.1190 \text { *** } \\
(0.0133)\end{array}$ & \\
\hline ICT Skills & & & & & $\begin{array}{c}2.0912 * * * \\
(0.1253)\end{array}$ \\
\hline Constant & $\begin{array}{c}4.9321 * * * \\
(0.0319)\end{array}$ & $\begin{array}{c}4.8839 * * * * \\
(0.0501)\end{array}$ & $\begin{array}{c}4.7476^{* * * *} \\
(0.0286)\end{array}$ & $\begin{array}{c}4.9799 * * * \\
(0.0396)\end{array}$ & $\begin{array}{c}3.3197 * * * \\
(0.1026)\end{array}$ \\
\hline Observations & 1,680 & 164 & 1,676 & 610 & 941 \\
\hline R-squared & 0.0100 & 0.4608 & 0.2013 & 0.1160 & 0.2287 \\
\hline Adjusted R-Squared & 0.0093 & 0.457 & 0.201 & 0.115 & 0.228 \\
\hline
\end{tabular}

\subsection{System GMM results on the effects of FDI, and ICT diffusion on inclusive growth}

In Table 5, the results on the effect of FDI and ICT diffusion on inclusive growth in SSA are presented. The baseline results in Column 1 show that human capital and financial deepening are positive and statistically significant. Albeit statistically insignificant, institutions for social 
protection enhance inclusive growth in SSA. Moreover, we find that inflation and vulnerable employment are harmful to the region's inclusive growth fight. 
Table 4: System GMM results on the effects of FDI and ICT diffusion on inclusive growth (Dependent variable: Inclusive growth)

\begin{tabular}{|c|c|c|c|c|c|c|c|c|c|c|}
\hline Variables & (1) & (2) & (3) & (4) & (5) & (6) & (7) & (8) & (9) & (10) \\
\hline Inclusive Growth (Lag) & $0.8193 * * *$ & $0.8299^{* * *}$ & $1.0229 * * *$ & $0.7828^{* * *}$ & $0.9834 * * *$ & $0.7932 * * *$ & $1.0244 * * *$ & $0.8182 * * *$ & $0.9843^{* * *}$ & $0.7686^{* * *}$ \\
\hline & $(0.0058)$ & $(0.0097)$ & $(0.0066)$ & $(0.0078)$ & $(0.0037)$ & $(0.0109)$ & $(0.0108)$ & $(0.0135)$ & $(0.0038)$ & $(0.0174)$ \\
\hline Vulnerable Employment & $\begin{array}{c}-0.0025^{* *} \\
(0.0009)\end{array}$ & $\begin{array}{c}-0.0030 * * * \\
(0.0008)\end{array}$ & $\begin{array}{c}-0.0013 * * * \\
(0.0003)\end{array}$ & $\begin{array}{c}-0.0022 * * * \\
(0.0005)\end{array}$ & $\begin{array}{c}-0.0002 * * \\
(0.0001)\end{array}$ & $\begin{array}{c}0.0001 \\
(0.0013)\end{array}$ & $\begin{array}{c}-0.0010^{* * * *} \\
(0.0003)\end{array}$ & $\begin{array}{r}-0.0024^{*} \\
(0.0014)\end{array}$ & $\begin{array}{c}0.0003 \\
(0.0002)\end{array}$ & $\begin{array}{c}-0.0026 \\
(0.0017)\end{array}$ \\
\hline Inflation & $-0.0004 * * *$ & $-0.0011 * * *$ & $-0.0002 * * *$ & $-0.0003 * * *$ & $-0.0002 * * *$ & $-0.0014 * * *$ & $-0.0002 * * *$ & $-0.0021 * * *$ & $-0.0001 * * *$ & $-0.0014 * * *$ \\
\hline & $(0.0001)$ & $(0.0001)$ & $(0.0000)$ & $(0.0001)$ & $(0.0000)$ & $(0.0001)$ & $(0.0001)$ & $(0.0002)$ & $(0.0000)$ & $(0.0002)$ \\
\hline Human Capital & $\begin{array}{l}0.9405^{*} \\
(0.5028)\end{array}$ & $\begin{array}{l}1.1365^{*} \\
(0.5758)\end{array}$ & $\begin{array}{c}0.1117 * * * \\
(0.0371)\end{array}$ & $\begin{array}{c}0.1612 \\
(0.1083)\end{array}$ & $\begin{array}{l}0.1501 \\
\quad(0.0897)\end{array}$ & $\begin{array}{c}0.4355^{* * *} \\
(0.0816)\end{array}$ & $\begin{array}{c}0.1789 * * \\
(0.0735)\end{array}$ & $\begin{array}{c}1.3124 \\
(1.1463)\end{array}$ & $\begin{array}{c}0.0452 \\
(0.1978)\end{array}$ & $\begin{array}{c}0.1075 \\
(0.4410)\end{array}$ \\
\hline Social Protection & $\begin{array}{c}0.0001 \\
(0.0007)\end{array}$ & $\begin{array}{c}0.0005 \\
(0.0007)\end{array}$ & $\begin{array}{c}0.0001 \\
(0.0001)\end{array}$ & $\begin{array}{l}-0.0007 \\
(0.0004)\end{array}$ & $\begin{array}{c}0.0011 * * * * \\
(0.0001)\end{array}$ & $\begin{array}{c}0.0025 * * * \\
(0.0005)\end{array}$ & $\begin{array}{l}0.0001 * \\
(0.0001)\end{array}$ & $\begin{array}{l}-0.0000 \\
(0.0009)\end{array}$ & $\begin{array}{c}0.0010^{* * * *} \\
(0.0004)\end{array}$ & $\begin{array}{l}0.0006 \\
(0.0006)\end{array}$ \\
\hline Financial Deepening & $\begin{array}{c}0.3052^{* * * *} \\
(0.0969)\end{array}$ & $\begin{array}{c}0.2254 * * \\
(0.1104)\end{array}$ & $\begin{array}{c}0.1444 * * * \\
(0.0468)\end{array}$ & $\begin{array}{c}0.7289 * * * \\
(0.0972)\end{array}$ & $\begin{array}{c}(0.0546 * * * \\
(0.0190)\end{array}$ & $\begin{array}{c}0.0904 \\
(0.0989)\end{array}$ & $\begin{array}{l}0.0878^{*} \\
(0.0516)\end{array}$ & $\begin{array}{c}0.7838^{* * * *} \\
(0.2135)\end{array}$ & $\begin{array}{c}0.0262 \\
(0.0209)\end{array}$ & $\begin{array}{c}1.6103 * * * \\
(0.2038)\end{array}$ \\
\hline FDI & & $\begin{array}{c}0.0322 * * * \\
(0.0031)\end{array}$ & & & & & $\begin{array}{c}0.0053^{* * * *} \\
(0.0004)\end{array}$ & $\begin{array}{c}0.0731 * * * \\
(0.0127)\end{array}$ & $\begin{array}{c}0.0005 \\
(0.0005)\end{array}$ & $\begin{array}{c}0.2865^{* * * *} \\
(0.0224)\end{array}$ \\
\hline ICT Diffusion & & & $\begin{array}{c}0.0547 * * * \\
(0.0078)\end{array}$ & & & & $\begin{array}{c}0.0355^{* *} \\
(0.0162)\end{array}$ & & & \\
\hline ICT Access & & & & $\begin{array}{c}0.0463^{* * *} \\
(0.0051)\end{array}$ & & & & $\begin{array}{c}0.0591 * * * \\
(0.0096)\end{array}$ & & \\
\hline ICT Usage & & & & & $\begin{array}{c}0.0122 * * * \\
(0.0036)\end{array}$ & & & & $\begin{array}{c}0.0235 * * * \\
(0.0051)\end{array}$ & \\
\hline ICT Skills & & & & & & $\begin{array}{c}0.5742 * * * \\
(0.0650)\end{array}$ & & & & $\begin{array}{c}0.6413^{* *} \\
(0.2606)\end{array}$ \\
\hline FDI× ICT Diffusion & & & & & & & $\begin{array}{c}0.0014 * * * \\
(0.0003)\end{array}$ & & & \\
\hline FDI $\times$ ICT Access & & & & & & & & $\begin{array}{c}0.0115^{* * * *} \\
(0.0022)\end{array}$ & & \\
\hline FDI $\times$ ICT Usage & & & & & & & & & $\begin{array}{c}0.0010 * * * \\
(0.0002)\end{array}$ & \\
\hline FDI $\times$ ICT Skills & & & & & & & & & & $\begin{array}{c}0.3492 * * * \\
(0.0310)\end{array}$ \\
\hline Constant & $\begin{array}{c}0.7279 * * \\
(0.2731)\end{array}$ & $\begin{array}{c}0.6025 * * \\
(0.2879)\end{array}$ & $\begin{array}{c}-0.1707 * * * \\
(0.0516)\end{array}$ & $\begin{array}{c}1.1756 * * * \\
(0.0715)\end{array}$ & $\begin{array}{c}0.1314 * * * \\
(0.0392)\end{array}$ & $\begin{array}{c}0.4236 * * * \\
(0.1362)\end{array}$ & $\begin{array}{c}-0.1128 \\
(0.0742)\end{array}$ & $\begin{array}{c}0.0779 \\
(0.5473)\end{array}$ & $\begin{array}{c}0.0081 \\
(0.0942)\end{array}$ & $\begin{array}{c}0.7969 * * \\
(0.3830)\end{array}$ \\
\hline Observations & 1,638 & 1,638 & 164 & 1,638 & 610 & 915 & 164 & 1,638 & 610 & 915 \\
\hline Countries & 42 & 42 & 32 & 42 & 41 & 42 & 32 & 42 & 41 & 42 \\
\hline Instruments & 39 & 39 & 30 & 39 & 39 & 39 & 30 & 39 & 39 & 39 \\
\hline Net-effect & - & - & - & - & - & - & 0.039 & 0.092 & 0.026 & 1.667 \\
\hline Joint Significance Test & - & - & - & - & - & - & 21.18 & 27.87 & 16.94 & 127.22 \\
\hline P-Value & - & - & - & - & - & - & 0.000 & 0.000 & 0.000 & 0.000 \\
\hline Wald Statistic & 137100 & 191193 & 496500 & 364509 & 101000 & 120800 & 165600 & 641000 & 545000 & 436800 \\
\hline Wald P-value & 0.000 & 0.000 & 0.000 & 0.000 & 0.000 & 0.000 & 0.000 & 0.000 & 0.000 & 0.000 \\
\hline Hansen P-Value & 0.347 & 0.312 & 0.951 & 0.302 & 0.464 & 0.494 & 0.967 & 0.238 & 0.631 & 0.649 \\
\hline $\mathrm{AR}(1)$ & 0.000 & 0.000 & 0.045 & 0.000 & 0.0220 & 0.001 & 0.0418 & 0.000 & 0.021 & 0.004 \\
\hline $\mathrm{AR}(2)$ & 0.0652 & 0.0696 & 0.787 & 0.0664 & 0.143 & 0.610 & 0.843 & 0.108 & 0.140 & 0.924 \\
\hline
\end{tabular}


The results in Columns $2-6$ provide evidence for the first hypothesis. First, FDI is positive and significant at the 1 per cent level. The magnitude of the coefficient indicates that a 1 per cent increase in FDI induces inclusive growth in the SSA by 0.03 per cent. Also, there is strong empirical evidence on the favourable effects of ICT diffusion, access, usage, and skills on inclusive growth in SSA. The results show that while ICT diffusion in general fosters inclusive growth by 0.05 per cent, ICT access, usage and skills drive inclusive growth in SSA by 0.04 per cent, 0.01 per cent, and 0.57 per cent, respectively (see Columns $3-6$ ).

Considering the rise in economic integration of the region after the implementation of the AfCFTA and the projected rise in FDI from 2022, our results should not be taken lightly. FDI can drive inclusive growth in SSA through poverty alleviation, corporate social responsibility and macroeconomic stability as job creation and access to a variety of goods and services are improved in line with expanding industrial base, forward and backward linkages and increased global value chain participation. The momentous rise in ICT diffusion can also be targeted to foster shared prosperity in SSA in several ways. For instance, in education, ICT diffusion can help level the playing field in SSA by enhancing access to knowledge/information, timely and low-cost research, and the streamlining of administrative procedures. In the health sector, the rise in ICT diffusion can be helpful in healthcare by speeding-up the delivery of drugs, data collection and storage, remote consultation and diagnosis, and quick response to epidemics/pandemics. Indeed, in Rwanda and Ghana for instance, lives are being saved through the use of drones ${ }^{10}$ for delivering drugs, blood and other materials to remote areas.

Also germane is the power of ICTs in informing policymakers and the public on the seriousness of potential environmental threats/natural disasters by enhancing spatial monitoring and coordinated responses. Further, withtech-hubs and industrial parks sproutingout in the SSA, markedly, in countries like South Africa, Ghana, Nigeria, Mauritius and Kenya, policymakers in SSA can equip the youthful population of the region through ICT diffusion to realise their innovative ideas and contribute meaningfully to national development. Moreover, ICT diffusion can promote good governance and accountability by enhancing administrative effectiveness ${ }^{11}$, efficiency and reach of public communication and interaction, which are essential for social inclusion and inclusive growth. Indeed, in many

\footnotetext{
${ }^{10}$ This service is provided by the company called Zipline.

${ }^{11}$ In most SSA countries, ICTs are facilitating the migration of paper-based documents and records onto digital formats in all ministries.
} 
countries of the region, policymakers are leveraging the power of ICT in providing public information, services and opportunities.

Finally, we find evidence for the last hypothesis. The relevance and uniqueness of this finding is that though FDI spurs inclusive growth in SSA, the effect is more remarkable in the presence of ICT diffusion in general, ICT skills, access and usage. Comparatively, the ICT skills and FDI pathway is the most remarkable channel in fostering inclusive growth in the SSA. The net-effect of boosting ICT diffusion, access, usage and skills in line with FDI on inclusive growth in SSA are 0.04, 0.09, 0.03 and 1.67 respectively (see Columns $7-10$ ). These net-effects are computed following equations (5), given the average FDI value of 2.939 .

$$
\begin{aligned}
& \frac{\partial(\text { igrowth })}{\partial(\text { ictdif })}=0.0355+(0.0014 \times 2.939)=0.0396 \\
& \frac{\partial(\text { igrowth })}{\partial(\text { ictaccess })}=0.0591+(0.0115 \times 2.939)=0.0928 \\
& \frac{\partial(\text { igrowth })}{\partial(\text { ictusage })}=0.0235+(0.0010 \times 2.939)=0.0264 \\
& \frac{\partial(\text { igrowth })}{\partial(\text { ictskills })}=0.6413+(0.3492 \times 2.939)=1.6675
\end{aligned}
$$

These findings provide support for the theorized claim that boosting ICT diffusion in the form of access, usage and skills can drive inclusive growth in the SSA. In the service sector for instance, ICT diffusion can provide a number of job opportunities in line with the growing demand for technicians, software and hardware engineers/technicians, repairers, distributors, and marketers. Also, considering the rise in FDI into SSA over the last decade and the expected rise in FDI in line with the AfCFTA, enhancing access to productive assets like ICTs can build the technical capacity of the masses/private sector to take advantage of the numerous economic opportunities FDI offers. The optimism is that through ICT diffusion, policymakers can spur innovation/ideation, product development, and technological transfer to harness the inclusive growth potential of the AfCFTA, which can create meaningful economic impacts that can reverberate throughout the region. Further, ICT diffusion can offer limitless opportunities to the masses in line with FDI by triggering intense competition, market reach, and scale economies. In the financial sector for instance, ICT diffusioncan 
attract FDI as it enhancesfinancial inclusion, allocation efficiency, and reduction in administrative and operational costs.

The ancillary findings are also in order - inflation and vulnerable employment are deleterious to shared prosperity in SSA. Though moderate effects, the result shows that a 1 per cent increase in inflation and vulnerable employment reduces inclusive growth in the SSA by 0.002 per cent (Column 8) and 0.001 (Column 7), respectively. The harmful effect of vulnerable employment and inflation on inclusive growth signifies the need for prudent macroeconomic management and the creation of decent economic opportunities, which are essential for sustaining wealth accumulation and the building of the capacity of the masses to prepare, withstand or cope with socioeconomic shocks. The effect of financial deepening in inducing inclusive growth is strong and pronounced. In Column 8 for instance, the results show that for every 1 per cent increase in financial deepening, inclusive growth is enhanced by 0.78 per cent. This is more so as credit constraint often hinders the expansion of the region's huge vulnerable businesses into at least formalized informal sector. Likewise, for every 1 per cent improvement in human capital development, there is a 0.43 upsurge in inclusive growth in SSA. Finally, we find that institutions for preventing, managing, and overcoming situations that adversely affect the welfare of the poor and vulnerable can have higher inclusive growth-inducing effects if well resourced. The reliability of the estimates are evident in the post estimation tests of $\operatorname{AR}(2)$, showing the absence of second-order serial correlation in the residuals, and the Hansen P-value, providing evidence of the validity of our instruments. Moreover, the number of instruments is consistently lower than the corresponding number of countries in each specification, which confirms the absence of instrument proliferation (Tchamyou et al. 2019a; Tchamyou 2019).

Overall, it is apparent form the findings in Table 4 that FDI modulate ICT dynamics to engender positive synergy effects on inclusive growth. Positive synergy effects build on the perspective that both the unconditional and conditional (i.e. interactive) effects of ICT dynamics on the outcome variable are positive. This conception of synergy is consistent with contemporary interactive regressions literature (Asongu and Acha-Anyi 2017; Asongu and Nwachukwu 2017).

\subsection{Robustness check for inclusive growth results}

To check the robustness of the estimates in Table 4, we use the inclusive growth index calculated via the principal component analysis (PCA).To this end, we follow the Asian Development Bank (2013)in selecting 15 variables that drive inclusive growth in the 
developing world. In Table5, the variables underpinning our inclusive growth index are presented.

Table 5: Variables used in constructing inclusive growth index

\begin{tabular}{|c|c|c|}
\hline Variable & Variable Definition & Source \\
\hline Women seats & $\begin{array}{l}\text { Women in parliaments are the percentage of parliamentary seats in a single } \\
\text { or lower chamber held by women. }\end{array}$ & WDI \\
\hline Poverty headcount & International poverty headcount (US $\$ 1.90$ ) & PED \\
\hline Sanitation & People using at least basic sanitation services & WDI \\
\hline GDP per capita & GDP per capita (US\$'2017 PPP) & WDI \\
\hline Social protection & Effectiveness of institutions for social protection rating ( $1=$ low to $6=$ high) & CPIA \\
\hline Social inclusion & Effectiveness of institutions for social inclusion rating ( $1=$ low to $6=$ high) & CPIA \\
\hline Electricity access & Electricity access (overall population) & WDI \\
\hline Clean fuel & $\begin{array}{l}\text { Access to clean fuels and technologies for cooking is the proportion of total } \\
\text { population primarily using clean cooking fuels and technologies for cooking. }\end{array}$ & WDI \\
\hline Gini & Gini index & WDI \\
\hline Rule of Law & Rule of law (estimate) & WGI \\
\hline Health expenditure & Government expenditure on health (\%GDP) & WDI \\
\hline Education expenditure & Government expenditure on education (\%GDP) & WDI \\
\hline Human capital index & Human Capital Index (HCI) (scale 0-1) & WDI \\
\hline Labour force & Labour force participation rate total (\% of total population ages $15-64$ ) & WDI \\
\hline Voice and accountability & $\begin{array}{l}\text { Freedom of the media and general public in terms of association, expression } \\
\text { and institutions of public governments }\end{array}$ & WGI \\
\hline
\end{tabular}

Note: WDI is World Development Indicators; WGI is Worldwide Governance Indicators; PED id Poverty and Equity Database; CPIA is Country Policy and Institutional Score Source: Authors' construct, 2021

The screeplot of the PCA in Figure 4shows a total of 15 principal components as defined in Table 5. Per the eigenvalue rule of at least 1 (Tchamyou et al. 2019b), the inclusive growth index is generated based on the first five components, which cummulatively explain 74.8 per cent information in the 15 components of inclusive growth (see results in Table 6).

Table 6: Principal components eigenvectors (Inclusive growth index)

\begin{tabular}{lcccc}
\hline Components & Eigenvalue & Difference & Proportion & Cumulative \\
\hline PC1 & $\mathbf{4 . 9 0 6}$ & $\mathbf{2 . 0 5 1}$ & $\mathbf{0 . 3 2 7}$ & $\mathbf{0 . 3 2 7}$ \\
PC2 & $\mathbf{2 . 8 5 5}$ & $\mathbf{1 . 5 8 3}$ & $\mathbf{0 . 1 9 0}$ & $\mathbf{0 . 5 1 7}$ \\
PC3 & $\mathbf{1 . 2 7 2}$ & $\mathbf{0 . 1 2 2}$ & $\mathbf{0 . 0 8 5}$ & $\mathbf{0 . 6 0 2}$ \\
PC4 & $\mathbf{1 . 1 5 0}$ & $\mathbf{0 . 1 1 3}$ & $\mathbf{0 . 0 7 7}$ & $\mathbf{0 . 6 7 9}$ \\
PC5 & $\mathbf{1 . 0 3 7}$ & $\mathbf{0 . 1 7 4}$ & $\mathbf{0 . 0 6 9}$ & $\mathbf{0 . 7 4 8}$ \\
PC6 & 0.863 & 0.221 & 0.058 & 0.806 \\
PC7 & 0.642 & 0.108 & 0.043 & 0.848 \\
PC8 & 0.534 & 0.064 & 0.036 & 0.884 \\
PC9 & 0.470 & 0.142 & 0.031 & 0.915 \\
PC10 & 0.329 & 0.051 & 0.022 & 0.937 \\
PC11 & 0.278 & 0.060 & 0.018 & 0.956 \\
PC12 & 0.218 & 0.005 & 0.015 & 0.970 \\
PC13 & 0.213 & 0.064 & 0.014 & 0.985 \\
PC14 & 0.149 & 0.065 & 0.010 & 0.994 \\
PC15 & 0.084 &. & 0.006 & 1.000
\end{tabular}

Source: Authors' construct, 2021 


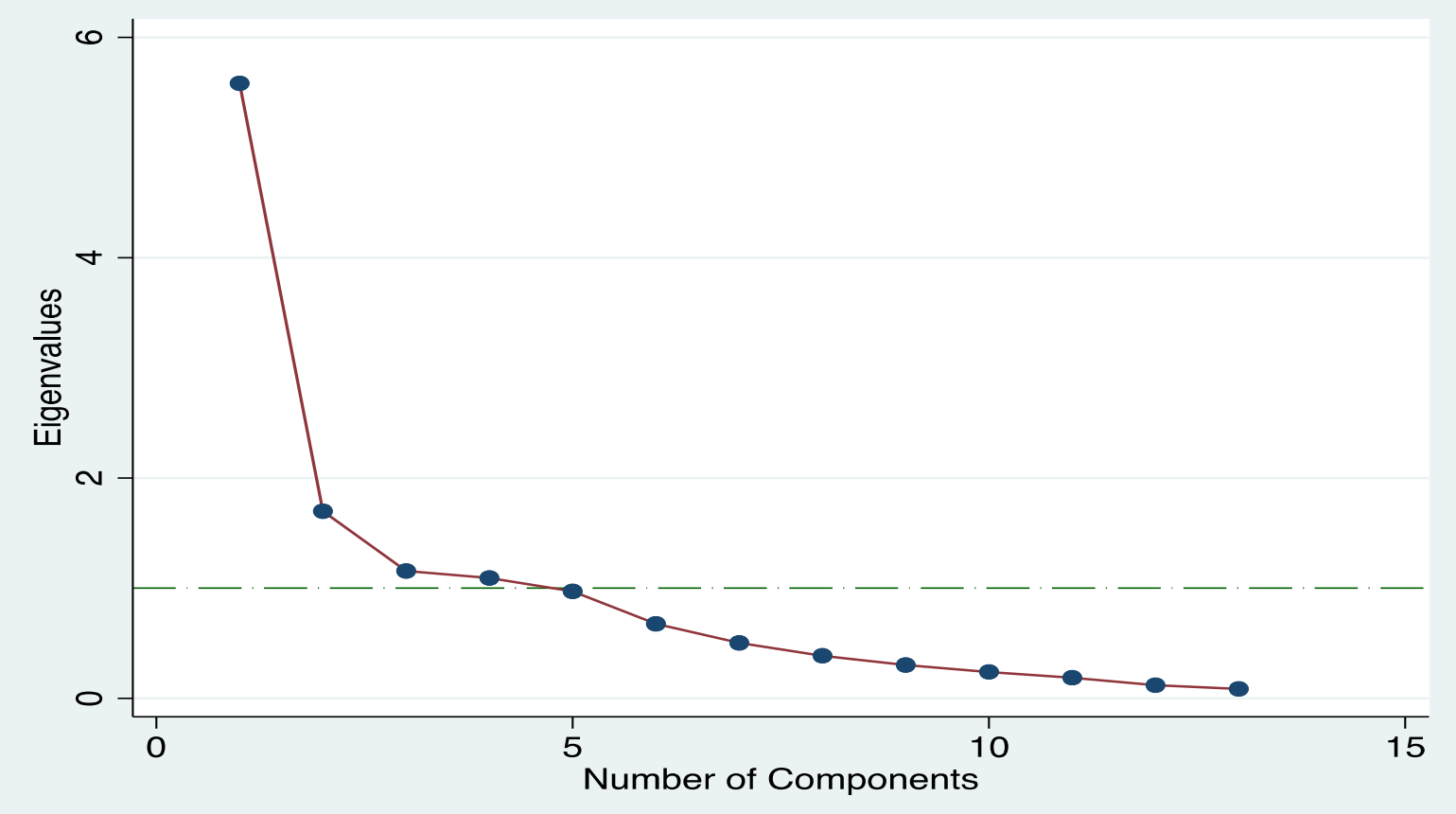

Figure 4: Screeplot of Principal Components of Inclusive Growth

\subsubsection{Robustness check results based on inclusive growth index}

From the baseline results in Column 1 of Table 7, financial deepening, human capital and social protection are positively related to inclusive growth though there is no statistical backing for human capital and social protection. The lag of inclusive growth is also strong and statistically significant irrespective of the type of model specification, signifying that inclusive growth momentum built in previous years is crucial for fostering inclusive efforts in present times. The results in Columns $2-6$ provide evidence for the first hypothesis of the study as all ICT variables and FDI are positively related to inclusive growth. For instance, we find that, for every 1 per cent improvement in ICT diffusion and access, inclusive growth is induced by 0.16 per cent (Column 3) and 1.45 per cent (Column 6), respectively. Again, the results show that 'ICT skills' is remarkable in fostering inclusive growth. This result appeals to logic as making sense of ICT access and usage require some level of ICT skills. 
Table 7: System GMM results on the effects of FDI and ICT diffusion on inclusive growth (Dependent variable: Inclusive Growth Index)

\begin{tabular}{|c|c|c|c|c|c|c|c|c|c|c|}
\hline Variables & (1) & (2) & (3) & $(4)$ & (5) & (6) & (7) & (8) & (9) & (10) \\
\hline Inclusive Growth Index (Lag) & $\begin{array}{c}0.6392 * * * \\
(0.0491)\end{array}$ & $\begin{array}{c}0.5971 * * * \\
(0.0599)\end{array}$ & $\begin{array}{c}0.9259 * * * \\
(0.0117)\end{array}$ & $\begin{array}{c}0.6588 * * * \\
(0.0474)\end{array}$ & $\begin{array}{c}0.6480 * * * \\
(0.0501)\end{array}$ & $\begin{array}{c}0.6860 * * * \\
(0.0429)\end{array}$ & $\begin{array}{c}0.9761 * * * \\
(0.0323)\end{array}$ & $\begin{array}{c}0.5796^{* * *} * \\
(0.0692)\end{array}$ & $\begin{array}{c}0.6211 * * * \\
(0.0835)\end{array}$ & $\begin{array}{c}0.6358 * * * \\
(0.0568)\end{array}$ \\
\hline Vulnerable Employment & $\begin{array}{c}0.0002 \\
(0.0015)\end{array}$ & $\begin{array}{c}0.0013 \\
(0.0015)\end{array}$ & $\begin{array}{c}-0.0030 * * \\
(0.0012)\end{array}$ & $\begin{array}{l}-0.0009 \\
(0.0018)\end{array}$ & $\begin{array}{l}-0.0005 \\
(0.0014)\end{array}$ & $\begin{array}{c}-0.0062 * * \\
(0.0025)\end{array}$ & $\begin{array}{c}0.0036 \\
(0.0021)\end{array}$ & $\begin{array}{l}-0.0042 \\
(0.0058)\end{array}$ & $\begin{array}{c}0.0021 \\
(0.0062)\end{array}$ & $\begin{array}{c}-0.0141 * * * \\
(0.0041)\end{array}$ \\
\hline Inflation & $\begin{array}{c}-0.0005^{* * * *} \\
(0.0001)\end{array}$ & $\begin{array}{c}-0.0004 * * * \\
(0.0001)\end{array}$ & $\begin{array}{c}0.0001 \\
(0.0001)\end{array}$ & $\begin{array}{c}0.0003 \\
(0.0003)\end{array}$ & $\begin{array}{c}0.0002 \\
(0.0002)\end{array}$ & $\begin{array}{l}-0.0002 \\
(0.0002)\end{array}$ & $\begin{array}{l}0.0003^{*} \\
(0.0002)\end{array}$ & $\begin{array}{c}0.0003 \\
(0.0004)\end{array}$ & $\begin{array}{c}-0.0007^{*} \\
(0.0004)\end{array}$ & $\begin{array}{l}-0.0004 \\
(0.0003)\end{array}$ \\
\hline Human Capital & $\begin{array}{c}0.0185 \\
(0.4324)\end{array}$ & $\begin{array}{c}0.1766 \\
(0.5094)\end{array}$ & $\begin{array}{l}-0.0072 \\
(0.1628)\end{array}$ & $\begin{array}{l}1.4660 * * \\
(0.5816)\end{array}$ & $\begin{array}{c}0.6065 \\
(0.5739)\end{array}$ & $\begin{array}{c}0.5405 \\
(0.3759)\end{array}$ & $\begin{array}{l}-0.5422 * \\
(0.2844)\end{array}$ & $\begin{array}{l}1.8031^{*} \\
(1.0599)\end{array}$ & $\begin{array}{l}-0.0550 \\
(0.8619)\end{array}$ & $\begin{array}{c}1.4786 * * \\
(0.5651)\end{array}$ \\
\hline Social Protection & $\begin{array}{c}0.0003 \\
(0.0012)\end{array}$ & $\begin{array}{c}0.0003 \\
(0.0014)\end{array}$ & $\begin{array}{c}0.0007 \\
(0.0007)\end{array}$ & $\begin{array}{c}0.0012 \\
(0.0019)\end{array}$ & $\begin{array}{c}0.0021 \\
(0.0015)\end{array}$ & $\begin{array}{c}0.0047 * * * \\
(0.0013)\end{array}$ & $\begin{array}{c}0.0029 * * * \\
(0.0009)\end{array}$ & $\begin{array}{c}0.0025 \\
(0.0029)\end{array}$ & $\begin{array}{l}-0.0019 \\
(0.0044)\end{array}$ & $\begin{array}{c}0.0078 * * * \\
(0.0019)\end{array}$ \\
\hline Financial Deepening & $\begin{array}{c}0.1741 * * * \\
(0.0293)\end{array}$ & $\begin{array}{c}0.3407^{* *} \\
(0.1685)\end{array}$ & $\begin{array}{c}0.5002 * * * \\
(0.0780)\end{array}$ & $\begin{array}{c}0.2937 \\
(0.4426)\end{array}$ & $\begin{array}{c}0.1924 \\
(0.3186)\end{array}$ & $\begin{array}{c}0.2337 \\
(0.1682)\end{array}$ & $\begin{array}{c}1.4152 * * * \\
(0.2237)\end{array}$ & $\begin{array}{c}0.2893 \\
(0.2570)\end{array}$ & $\begin{array}{c}0.0170 \\
(0.1088)\end{array}$ & $\begin{array}{c}-0.3378 \\
(0.3458)\end{array}$ \\
\hline FDI & & $\begin{array}{c}0.0074 \\
(0.0083)\end{array}$ & & & & & $\begin{array}{c}0.0006 \\
(0.0101)\end{array}$ & $\begin{array}{c}0.0051 \\
(0.0088)\end{array}$ & $\begin{array}{l}0.0046 \\
\quad(0.0118)\end{array}$ & $\begin{array}{c}0.1058 \\
(0.0716)\end{array}$ \\
\hline ICT Diffusion & & & $\begin{array}{c}0.1620 * * * * \\
(0.0456)\end{array}$ & & & & $\begin{array}{l}0.2678^{* * * *} \\
(0.0565)\end{array}$ & & & \\
\hline ICT Access & & & & $\begin{array}{c}0.0246 \\
(0.0212)\end{array}$ & & & & $\begin{array}{l}-0.0659 \\
(0.0498)\end{array}$ & & \\
\hline ICT Usage & & & & & $\begin{array}{c}0.0311 \\
(0.0331)\end{array}$ & & & & $\begin{array}{c}0.0336 \\
(0.1632)\end{array}$ & \\
\hline ICT Skills & & & & & & $\begin{array}{c}1.4581 * * * * \\
(0.3201)\end{array}$ & & & & $\begin{array}{c}3.2237 * * * * \\
(0.7143)\end{array}$ \\
\hline FDI $\times$ ICT Diffusion & & & & & & & $\begin{array}{c}0.0233 * * * \\
(0.0033)\end{array}$ & & & \\
\hline FDI $\times$ ICT Access & & & & & & & & $\begin{array}{c}0.0027 \\
(0.0027)\end{array}$ & & \\
\hline FDI $\times$ ICT Usage & & & & & & & & & $\begin{array}{c}0.0031 \\
(0.0121)\end{array}$ & \\
\hline FDI $\times$ ICT Skills & & & & & & & & & & $\begin{array}{c}0.1577 * * \\
(0.0750)\end{array}$ \\
\hline Constant & $\begin{array}{l}-0.1297 \\
(0.2033)\end{array}$ & $\begin{array}{l}-0.2397 \\
(0.2382)\end{array}$ & $\begin{array}{c}-0.1294 * \\
(0.0699)\end{array}$ & $\begin{array}{c}-0.5263 * * * * \\
(0.1862)\end{array}$ & $\begin{array}{c}-0.2598 \\
(0.2296)\end{array}$ & $\begin{array}{c}1.6333^{* * * *} \\
(0.4051)\end{array}$ & $\begin{array}{c}0.1044 \\
(0.2345)\end{array}$ & $\begin{array}{l}-0.3815 \\
(0.4335)\end{array}$ & $\begin{array}{l}-0.1629 \\
(0.3546)\end{array}$ & $\begin{array}{c}3.3080^{* * * *} \\
(0.7649)\end{array}$ \\
\hline Observations & 569 & 569 & 164 & 569 & 569 & 337 & 164 & 569 & 569 & 337 \\
\hline Countries & 41 & 41 & 32 & 41 & 41 & 38 & 32 & 41 & 41 & 38 \\
\hline Instruments & 25 & 25 & 25 & 25 & 25 & 23 & 21 & 25 & 25 & 23 \\
\hline Net-effect & - & - & - & - & - & - & 0.336 & - & - & 3.687 \\
\hline Joint Significance Test & - & - & - & - & - & - & 48.91 & - & - & 4.42 \\
\hline P-Value & - & - & - & - & - & - & 0.000 & - & - & 0.042 \\
\hline Wald Statistic & 45.80 & 26.92 & 16606 & 43.24 & 43.45 & 690.9 & 39127 & 27.46 & 11.38 & 104.6 \\
\hline Wald P-value & 0.000 & 0.000 & 0.000 & 0.000 & 0.000 & 0.000 & 0.000 & 0.000 & 0.000 & 0.000 \\
\hline Hansen P-Value & 0.472 & 0.353 & 0.765 & 0.757 & 0.565 & 0.593 & 0.421 & 0.728 & 0.776 & 0.137 \\
\hline $\mathrm{AR}(1)$ & 0.013 & 0.010 & 0.012 & 0.017 & 0.013 & 0.102 & 0.081 & 0.012 & 0.017 & 0.038 \\
\hline $\operatorname{AR}(2)$ & 0.249 & 0.271 & 0.609 & 0.247 & 0.249 & 0.343 & 0.924 & 0.185 & 0.236 & 0.094 \\
\hline
\end{tabular}


Moreover, there is evidence for the second hypothesis of the study. Indeed, all the ICT and FDI pathways are positive (see, Columns $7-10$ ). However, statistical significance is evident for the FDI - ICT diffusion, and FDI - ICT skills pathways. The net-effects are therefore computed for these two significant pathways. For the FDI - ICT diffusion pathway, we find a net-effect of 0.33 per cent, and a remarkable 3.68 per cent for the FDI and ICT skills interaction. These pathways are calculated as follows taking into account the average FDI value of 2.939 .

$$
\begin{aligned}
& \frac{\partial(\text { igindex })}{\partial(\text { ictdif })}=0.2678+(0.0233 \times 2.939)=0.3363 \\
& \frac{\partial(\text { igindex })}{\partial(\text { ictskills })}=3.2237+(0.1577 \times 2.939)=3.6872
\end{aligned}
$$

The results show that ICT diffusion can amplify the effect of FDI on inclusive growth. Possible opportunities FDI provide in line with growing ICT diffusion is employment, wider markets, innovation, repairs, preservation of jobs, and knowledge transfer. Further, access to productive assets like ICTs in this current information age can build the entrepreneurial or innovative capacity of the active population while enhancing access to opportunities. This is more so as UNCTAD (2019) indicate that inflow of FDI into the region has been to the extractive, aviation, and telecommunication sector industries, which require ICT skills to take advantage of associated opportunities. Additionally, with growing tech-labs and start-ups in the region, enhancing ICT diffusion can possibly prevent human resource wastage by empowering the teaming youth to realise their innovative potentials, earn decent living while contributing to national development. The pooled least squares estimates, which we provide as additional results in the Appendix section also yield similar effects (see Table A.2).

\subsection{Conclusion and policy recommendations}

This study contributes to the discourse on how SSA can foster inclusive growth post COVID19. To this end, we deviate from the proliferation of opinions on how this can be achieved without empirical content. Motivated by the momentous rise in ICT diffusion and the expected rise in FDI inflow into SSA following the coming into force of the AfCFTA, we examine the direct and indirect effects of ICT diffusion and FDI on inclusive growth in SSA. We use data for the period 1980 - 2019 on 42 SSA countries for the analysis. We provide 
evidence robust to several specifications from the least squares and the dynamic system GMM to show that: (1) both ICT diffusion and FDI foster inclusive growth in SSA, (2) the inclusive growth-inducing effect of FDI is rather remarkable in the presence of greater ICT diffusion, (3) compared to ICT access and usage, ICT skills is more effective in driving inclusive growth in SSA. Overall FDI modulates ICT dynamics to engender positive synergy effects on inclusive growth.

Considering strides made by countries like Hong Kong, China, Singapore and Taiwan in recent times through ICT diffusion and FDI, our results offer glimmers of hope in fostering shared prosperity in SSA. First, our results show that ICTs can offer policy makers interested in SSA's growth agenda realistic means of addressing human resource wastage and social tensions by enhancing equity in education, healthcare delivery, access to opportunities, accountability, and social inclusion. Second, FDI can induce inclusive growth through poverty alleviation, macroeconomic stability, increased global value chain participation and corporate social responsibility. Our pathway results on FDI and ICT indicate that creating shared opportunities in SSA may not be about enhancing infrastructural investment per se but infrastructural development of opportunities, inclusiveness, and gender impartiality.

We recommend that policymakers should channel resources to boost ICT skills, access, and usage in the region. This can be enhanced if organisations interested in the SSA agenda such as the African Development Bank and the World Bank provide technical, logistical and monetary support to complement various governments efforts in boosting ICT diffusion in the region. This also calls for policy actions aimed at developing the region's tech-hubs and industrial parks to promote high-tech product commercialization, patent development and incubation to offer technical and logistical support for the region's youthful and innovative population to realistically contribute to national development. To attract FDI into the region, various governments should strive to improve the legal framework, energy supply and infrastructure of which digital infrastructure is a major component. To take advantage of the AfCFTA, policy makers are advised to support the private sector in building capacity to deepen indigenous forward and backward linkages, which are paramount for improving the region's industrial base, global value chain participation and opportunity creation.

This study leaves room for improvement, especially as it relates to exploring other mechanisms by which FDI or other external flows (e.g., foreign aid and remittances) influence inclusive development. Moreover, other dimensions of inclusive development such as gender political and economic empowerment can be envisaged. 
This research did not receive any specific grant from funding agencies in the public, commercial, or not-for-profit sectors.

\section{Reference}

Acemoglu \& Robinson (2012). Why Nations Fail: The Origins of Power, Prosperity and Poverty. Profile Books, London.

Adeleye, B. N., Adedoyin, F., \& Nathaniel, S. (2020). The criticality of ICT-trade nexus on economic and inclusive growth. Information Technology for Development, 1-21

Adeleye, N., \& Eboagu, C. (2019). Evaluation of ICT development and economic growth in Africa. NETNOMICS: Economic Research and Electronic Networking, 20(1), 31-53.

African Development Bank, 2010. African Development Report. African Development Bank, Tunis.

Afutu-Kotey, R. L., Gough, K. W., \&Owusu, G., (2017). "Young Entrepreneurs in the Mobile Telephony Sector in Ghana: From Necessities to Aspirations", Journal of African Business, 18(4), pp. 476-491.

Albiman, M. M., \& Sulong, Z. (2017). The linear and non-linear impacts of ICT on economic growth, of disaggregate income groups within SSA region. Telecommunications Policy, 41(7-8), 555572.

Allen, F., McAndrews, J. and Strahan, P. (2001), "E-finance: an introduction", Working paper, Financial Institutions Center, The Wharton School, University of Pennsylvania, Philadelphia

Ali, I. \& Son, H. (2007). "Measuring Inclusive Growth," Asian Development Review, 24(1), 11-31.

Anand, R., Mishra, S. \& Peiris, S. (2013). Inclusive growth: measurement and determinants. IMF Working Papers No. 13/135.

Arellano, M., \& Bover, O. (1995). Another look at the instrumental variable estimation of errorcomponents models. Journal of Econometrics, 68(1), 29-51. Asian Development Bank. (2013).

Framework of inclusive growth indicators: Key indicators for Asia and the Pacific. Mandaluyong City, Philippines: Asian Development Bank.

Asongu, S. A. \& Acha-Anyi, P. N., (2017). ICT, conflicts in financial intermediation and financial access: evidenceof synergy and threshold effects, Netnomics, 18(2-3), 131-168.

Asongu, S. A., \& Odhiambo, N. M. (2020). Foreign direct investment, information technology and economic growth dynamics in Sub-Saharan Africa. Telecommunications Policy, 44(1), 101838.

Asongu, S. A., Anyanwu, J. C., \& Tchamyou, V. S. (2019). Technology-driven information sharing and conditional financial development in Africa. Information Technology for Development, 25(4), 630-659.

Asongu, S. A, \& Nwachukwu, J. C., (2017). The synergy of financial sector development and information sharing in financial access: Propositions and empirical evidence. Research in International Business and Finance, 40 (April), 242-258.

Asongu, S. A., \& Nwachukwu, J. C. (2018). Openness, ICT and entrepreneurship in sub-Saharan Africa. Information Technology \& People, 31(1), 278-303

Asongu, S. A., \& Le Roux, S. (2017). Enhancing ICT for inclusive human development in SubSaharan Africa. Technological Forecasting and Social Change, 118, 44-54.

Asongu, S. A. (2013). How has mobile phone penetration stimulated financial development in Africa? Journal of African Business, 14(1), 7-18.

Bedia, A.S. (1999) 'The role of information and communication technologies in economic development - a partial survey', ZEF - Discussion Papers on Development Policy No. 7, Bonn: Center for Development Research (ZEF).

Bengoa, M., \& Sanchez-Robles, B. (2003). Does foreign direct investment promote growth? Recent evidence from Latin America. Universidad de Cantabria, mimeo. 
Brown, M.M. (2001) 'Can ICTs address the needs of the poor? A commentary from UNDP', Choices Magazine, June Edition.

Berg, M. A. \& Ostry, M. J. D. (2011). Inequality and unsustainable growth: Two sides of the same coin? International Monetary Fund.

Brown, C. S., Ravallion, M., \& Van De Walle, D. (2020). Can the World's poor protect themselves from the New Coronavirus? (No. w27200). National Bureau of Economic Research.

Calderón, C. \& Servén, L. (2014). Infrastructure, Growth and Inequality (Policy Research Working Paper). World Bank.

Castells, M. (1999). Information technology, globalization and social development (No. 114).

Geneva: UNRISD.

Chowdhury, N. (2000). Information and Communication Technologies And Ifpri's Mandate: A Conceptual Framework (No. 594-2016-39941).

Duncombe, R. (2006). Using the livelihoods framework to analyze ICT applications for poverty reduction through microenterprise. Information Technologies \& International Development, $3(3), 81$.

Donou-Adonsou, F. (2019). Technology, education, and economic growth in Sub-Saharan Africa. Telecommunications policy, 43(4), 353-360.

Durham, J. B. (2004). Economic growth and institutions: Some sensitivity analyses, 19612000. International Organization, 485-529.

Ejemeyovwi, J. O., Osabuohien, E. S., \& Osabohien, R. (2018). ICT investments, human capital development and institutions in ECOWAS. International Journal of Economics and Business Research, 15(4), 463-474.

Estache, A., Ianchovichina, E., Bacon, R., \& Salamon, I. (2013). Infrastructure and employment creation in the Middle East and North Africa. The World Bank.

Gygli, S., Haelg, F., Potrafke, N., \& Sturm, J. E. (2019). The KOF Globalisation Index - Revisited. Review of International Organizations, 14(3), 543-574.

Grace, J., Kenny, C., \& Qiang, C. Z. W. (2003). Information and communication technologies and broad-based development: A partial review of the evidence. World Bank.

Greenwald, B., \& Stiglitz, J. E. (2013). Industrial policies, the creation of a learning society, and economic development. In The Industrial Policy Revolution I (pp. 43-71). Palgrave Macmillan, London.

Hassan, S. T., Baloch, M. A., Mahmood, N., \& Zhang, J. (2019). Linking economic growth and ecological footprint through human capital and biocapacity. Sustainable Cities and Society, 47, 101516.

Humbani, M., \& Wiese, M. (2018). A cashless society for all: Determining consumers' readiness to adopt mobile payment services. Journal of African Business, 19(3), 409-429.

ILO (2020a). COVID-19 Cruelly Highlights Inequalities and Threatens to Deepen Them. ILO Newsroom

. (2020b). World Economic and Social Outlook Trends - 2020. International Labour Office Geneva.

IMF (2020a). World Economic Outlook: A Long and Difficult Ascent. October. Washington, DC,

IMF \& World Bank. (2020). Enhancing Access to Opportunities. International Monetary Fund and World Bank, Washington, DC: World Bank.

Johnson, O. D. (2016). Information and communication technologies adoption and inclusive growth: the ICT-inclusive growth pyramid approach. Unpublished Masters

Dissertation submitted to Department of Economics \& Development Studies, Covenant University, Ota, Ogun State, Nigeria.

Kwan, L.Y-Y, \& Chiu, C-Y (2015). Country variations in different innovation outputs: The interactive effect of institutional support and human capital, Journal of OrganisationalBehavior, 36(7), 1050-1070.

Kotler, P., \& Lee, N. (2005). Best of breed: When it comes to gaining a market edge while supporting a social cause,"corporate social marketing" leads the pack. Social marketing quarterly, 11(34), 91-103. 
Kovacevic, M., \& Jahic, A. (2020). COVID-19 and human development. Exploring global preparedness and vulnerability. Human Development Report Office. New York: United Nations Development Programme.

Lahoti, R., Jayadev, A., \& Reddy, S. (2016). The global consumption and income project (GCIP): An overview. Journal of Globalization and Development, 7(1), 61-108.

Li, X., \& Liu, X. (2005). Foreign direct investment and economic growth: an increasingly endogenous relationship. World development, 33(3), 393-407.

Lustig, N., Lopez-Calva, L. F., \& Ortiz-Juarez, E. (2012). Declining inequality in Latin America in the 2000s: the cases of Argentina, Brazil, and Mexico. The World Bank.

Messer, N., \& Townsley, P. (2003). Local institutions and livelihoods: Guidelines for analysis. Rome: Food and Agriculture Organisation.

Mengesha, G. H., \& Garfield, M. J. (2019). A contextualized IT adoption and use model for telemedicine in Ethiopia. Information Technology for Development, 25(2), 184-203.

Mihalache-O'Keef, A., \& Li, Q. (2011). Modernization vs. dependency revisited: effects of foreign direct investment on food security in less developed countries. International Studies Quarterly, 55(1), 71-93.

Mody, A. (1997). Infrastructure strategies in East Asia: The untold story. Washington, DC: World Bank.

Muto, M., \& Yamano, T. (2009). The impact of mobile phone coverage expansion on market participation: Panel data evidence from Uganda. World Development, 37(12), 1887-1896.

Myovella, G., Karacuka, M., \& Haucap, J. (2020). Digitalization and economic growth: A comparative analysis of Sub-Saharan Africa and OECD economies. Telecommunications Policy, 44(2), 101856.

OECD (2020a). Investment in the MENA region in the time of Covid-19, June 4, 2020. . (2018). The Future of Education and Skills: Education 2030 (Paris)

Ohlin BG. 1933. Interregional and International Trade. Harvard University Press: Cambridge, MA.

Palvia, P., Baqir, N., \& Nemati, H. (2018). ICT for socio-economic development: A citizens' perspective. Information \& Management, 55(2), 160-176.

Paramasivan, S. Mani, K. \& Utpal, C. (2014). A Theoretical Model for Inclusive Economic Growth in Indian Context. International Journal of Humanities and Social Science 4(13), 228-234.

Pickett, K. E., \& Wilkinson, R. G. (2015). Income inequality and health: a causal review. Social Science \& Medicine, 128, 316-326.

. (2010). Inequality: an under acknowledged source of mental illness and distress. The British Journal of Psychiatry, 197(6), 426-428.

Ravallion, M., \& Chen, S. (2019). Global poverty measurement when relative income matters. Journal of Public Economics, 177, 104046 (2004). Measuring Pro-Poor Growth. Economics Letters, 78: 93-99.

Rondović, B., Djuričković, T., \& Kašćelan, L. (2019). Drivers of E-business diffusion in tourism: a decision tree approach. Journal of theoretical and applied electronic commerce research, 14(1), 30-50.

Salahuddin, M., \& Gow, J. (2016). The effects of Internet usage, financial development and trade openness on economic growth in South Africa: A time series analysis. Telematics and Informatics, 33(4), 1141-1154.

Samuelson, P. A. (1939). Interactions between the multiplier analysis and the principle of acceleration. The Review of Economics and Statistics, 21(2), 75-78.

Sassi, S., \& Goaied, M. (2013). Financial development, ICT diffusion and economic growth: Lessons from MENA region. Telecommunications Policy, 37(4-5), 252-261.

Sen, Amartya K. (1999). Development As Freedom, Oxford: Oxford University Press.

Shamim, F. (2007). The ICT environment, financial sector and economic growth: a cross-country analysis. Journal of Economic Studies, 34(4), 352-370.

Solomon, A. O. (2011). The role of households in solid waste management in East Africa capital cities (Vol. 4). Wageningen Academic Publishers.

Stolper, W. F., \& Samuelson, P. A. (1941). Protection and real wages. The Review of Economic Studies, 9(1), 58-73. 
Svirydzenka, K. (2016). Introducing a new broad-based index of financial development. International Monetary Fund, Washington, DC.

Tchamyou, V. S. (2017). The Role of Knowledge Economy in African Business. Journal of the Knowledge Economy, 8(4), pp. 1189-1228.

Tchamyou, V. S. (2019). The Role of Information Sharing in Modulating the Effect of Financial Access on Inequality. Journal of African Business, 20(3), 317-338.

Tchamyou, V. S. (2020). Financial access, governance and the persistence of inequality in Africa: Mechanisms and policy instruments. Public Affairs, DOI: 10.1002/pa.2201.

Tchamyou, V. S., \& Asongu, S. A. (2017). Information sharing and financial sector development in Africa. Journal of African Business, 18(1), 24-49.

Tchamyou, V. S., Asongu, S. A., \& Odhiambo, N. M. (2019b). The role of ICT in modulating the effect of education and lifelong learning on income inequality and economic growth in Africa. African Development Review, 31(3), 261-274.

Tchamyou, V.S., Erreygers, G., \& Cassimon, D. (2019a). Inequality, ICT and Financial Access in Africa. Technological Forecasting and Social Change,139(February), 169184.

Tella, S. A., \& Alimi, O. Y. (2016). Determinants of inclusive growth in Africa: Role of health and demographic changes. African Journal of Economic Review, 4(2), 138-146.

UNCTAD. (2020). World Investment Report: International Production Beyond The Pandemic. UNCTAD, Geneva.

. (2019). World Investment Report: Global Investment Trends and Prospects 2019: Special Economic Zones. UNCTAD, Geneva.

. (2013). World Investment Report. UNCTAD, Geneva.

World Bank. (2021). World Development Indicators. April 2021. Washington, DC: World Bank.

. (2020a). Global Economic Prospects, June 2020. Washington, DC: World Bank.

. (2020b). Poverty and Shared Prosperity 2020: Reversals of Fortunes. October. Washington, $D C$ : World Bank.

. (2014). World Development Indicators. March 2014. Washington, DC: World Bank. 


\section{APPENDICES}

Table A.1: Pairwise correlations

\begin{tabular}{|c|c|c|c|c|c|c|c|c|c|c|c|c|c|c|}
\hline Variables & (1) & (2) & (3) & (4) & (5) & (6) & (7) & (8) & (9) & $(10)$ & (11) & (12) & (13) & (14) \\
\hline (1) Inclusive Growth & 1.000 & & & & & & & & & & & & & \\
\hline (2) Inclusive Growth Index & -0.173 & 1.000 & & & & & & & & & & & & \\
\hline (3) GDP Per Capita & 0.370 & -0.087 & 1.000 & & & & & & & & & & & \\
\hline (4) Gini Index & 0.032 & 0.009 & -0.104 & 1.000 & & & & & & & & & & \\
\hline (5) FDI & 0.041 & -0.040 & 0.098 & -0.095 & 1.000 & & & & & & & & & \\
\hline (6) Vulnerable Employment & -0.250 & 0.102 & -0.521 & 0.032 & -0.014 & 1.000 & & & & & & & & \\
\hline (7) Inflation & -0.018 & 0.042 & 0.100 & -0.237 & 0.192 & -0.067 & 1.000 & & & & & & & \\
\hline (8) Human Capital & 0.308 & 0.081 & 0.610 & -0.002 & 0.028 & -0.311 & -0.006 & 1.000 & & & & & & \\
\hline (9) ICT Diffusion & 0.716 & 0.029 & 0.715 & -0.180 & 0.194 & -0.576 & 0.003 & 0.536 & 1.000 & & & & & \\
\hline (10) ICT Access & 0.265 & 0.054 & 0.734 & -0.057 & 0.123 & -0.436 & 0.106 & 0.625 & 0.707 & 1.000 & & & & \\
\hline (11) ICT Usage & 0.121 & 0.030 & 0.703 & -0.165 & 0.076 & -0.220 & -0.062 & 0.426 & 0.642 & 0.737 & 1.000 & & & \\
\hline (12) ICT Skills & 0.271 & 0.122 & 0.409 & -0.234 & 0.195 & -0.668 & 0.263 & 0.374 & 0.721 & 0.415 & 0.253 & 1.000 & & \\
\hline (13) Financial Deepening & 0.262 & 0.062 & 0.695 & -0.156 & 0.196 & -0.392 & 0.174 & 0.635 & 0.740 & 0.775 & 0.568 & 0.487 & 1.000 & \\
\hline (14) Social Protection & 0.045 & 0.012 & 0.172 & 0.054 & 0.016 & 0.048 & -0.005 & 0.100 & 0.152 & 0.161 & 0.251 & -0.074 & 0.116 & 1.000 \\
\hline
\end{tabular}

Source: Author's construct, 2021 
Table A.2: PooledOLS results on the effects of FDI and ICT diffusion on inclusive growth (Dependent variable: Inclusive growth)

\begin{tabular}{|c|c|c|c|c|c|c|c|c|c|c|}
\hline Variables & (1) & (2) & (3) & (4) & (5) & (6) & (7) & (8) & (9) & (10) \\
\hline Vulnerable Employment & $\begin{array}{c}-0.0168 * * * \\
(0.0012)\end{array}$ & $\begin{array}{c}-0.0170 * * * \\
(0.0012)\end{array}$ & $\begin{array}{c}-0.0046^{* *} \\
(0.0022)\end{array}$ & $\begin{array}{c}-0.0160 * * * \\
(0.0012)\end{array}$ & $\begin{array}{c}-0.0149 * * * \\
(0.0015)\end{array}$ & $\begin{array}{c}-0.0117 * * * \\
(0.0017)\end{array}$ & $\begin{array}{c}-0.0049 * * \\
(0.0023)\end{array}$ & $\begin{array}{c}-0.0157 * * * \\
(0.0015)\end{array}$ & $\begin{array}{c}-0.0161 * * * \\
(0.0012)\end{array}$ & $\begin{array}{c}-0.0114 * * * \\
(0.0017)\end{array}$ \\
\hline Inflation & $\begin{array}{c}0.0014 * * * \\
(0.0005)\end{array}$ & $\begin{array}{c}0.0012 * * \\
(0.0005)\end{array}$ & $\begin{array}{c}0.0005 \\
(0.0009)\end{array}$ & $\begin{array}{c}0.0014 * * * \\
(0.0005)\end{array}$ & $\begin{array}{c}-0.0017 * * * \\
(0.0007)\end{array}$ & $\begin{array}{l}-0.0000 \\
(0.0007)\end{array}$ & $\begin{array}{c}0.0005 \\
(0.0009)\end{array}$ & $\begin{array}{c}-0.0017 * * \\
(0.0007)\end{array}$ & $\begin{array}{c}0.0012 * * \\
(0.0005)\end{array}$ & $\begin{array}{l}-0.0002 \\
(0.0007)\end{array}$ \\
\hline Human Capital & $\begin{array}{c}3.5764 * * * \\
(0.4389)\end{array}$ & $\begin{array}{c}3.6808 * * * \\
(0.4404)\end{array}$ & $\begin{array}{c}1.8879 * * * \\
(0.6491)\end{array}$ & $\begin{array}{c}3.2165^{* * * *} \\
(0.4531)\end{array}$ & $\begin{array}{c}1.8948 * * * \\
(0.5173)\end{array}$ & $\begin{array}{c}2.6999 * * * \\
(0.5335)\end{array}$ & $\begin{array}{c}1.6191 * * \\
(0.6479)\end{array}$ & $\begin{array}{c}1.9394 * * * \\
(0.5184)\end{array}$ & $\begin{array}{c}3.3213^{* * *} \\
(0.4547)\end{array}$ & $\begin{array}{c}2.6073 * * * \\
(0.5391)\end{array}$ \\
\hline Social Protection & $\begin{array}{c}0.0041^{* *} \\
(0.0016)\end{array}$ & $\begin{array}{c}0.0041^{* *} \\
(0.0016)\end{array}$ & $\begin{array}{c}0.0062^{* *} \\
(0.0030)\end{array}$ & $\begin{array}{c}0.0035^{* *} \\
(0.0016)\end{array}$ & $\begin{array}{c}0.0009 \\
(0.0021)\end{array}$ & $\begin{array}{c}0.0062^{* * *} \\
(0.0021)\end{array}$ & $\begin{array}{c}0.0069 * * \\
(0.0030)\end{array}$ & $\begin{array}{c}0.0011 \\
(0.0021)\end{array}$ & $\begin{array}{c}0.0035 * * \\
(0.0016)\end{array}$ & $\begin{array}{c}0.0058^{* * * *} \\
(0.0021)\end{array}$ \\
\hline Financial Deepening & $\begin{array}{c}1.4918^{* * * *} \\
(0.2596)\end{array}$ & $\begin{array}{c}1.3624 * * * \\
(0.2649)\end{array}$ & $\begin{array}{c}1.3304 * * * \\
(0.3331)\end{array}$ & $\begin{array}{c}0.9524 * * * \\
(0.3182)\end{array}$ & $\begin{array}{c}1.4448^{* * * *} \\
(0.2883)\end{array}$ & $\begin{array}{c}1.7816^{* * * *} \\
(0.2990)\end{array}$ & $\begin{array}{c}1.3550^{* * * *} \\
(0.3308)\end{array}$ & $\begin{array}{c}1.3143 * * * \\
(0.2955)\end{array}$ & $\begin{array}{c}0.8403 * * \\
(0.3314)\end{array}$ & $\begin{array}{c}2.0171 * * * \\
(0.3185)\end{array}$ \\
\hline FDI & & $\begin{array}{c}0.0093 * * \\
(0.0039)\end{array}$ & & & & & $\begin{array}{c}0.0142 * * \\
(0.0062)\end{array}$ & $\begin{array}{c}0.0024 \\
(0.0037)\end{array}$ & $\begin{array}{c}0.0095 * * \\
(0.0041)\end{array}$ & $\begin{array}{c}0.0640 * * * \\
(0.0205)\end{array}$ \\
\hline ICT Diffusion & & & $\begin{array}{c}0.2027 * * * \\
(0.0722)\end{array}$ & & & & $\begin{array}{c}0.1646 * * \\
(0.0799)\end{array}$ & & & \\
\hline ICT Access & & & & $\begin{array}{c}0.0249 * * * \\
(0.0084)\end{array}$ & & & & & $\begin{array}{c}0.0256^{* * * *} \\
(0.0091)\end{array}$ & \\
\hline ICT Usage & & & & & $\begin{array}{c}0.0210 \\
(0.0140)\end{array}$ & & & $\begin{array}{c}0.0049 \\
(0.0168)\end{array}$ & & \\
\hline ICT Skills & & & & & & $\begin{array}{c}0.6194 * * * \\
(0.1695)\end{array}$ & & & & $\begin{array}{c}0.7918 * * * \\
(0.1806)\end{array}$ \\
\hline FDI $\times$ ICT Diffusion & & & & & & & $\begin{array}{l}0.0081^{*} \\
(0.0042)\end{array}$ & & & \\
\hline FDI $\times$ ICT Usage & & & & & & & & $\begin{array}{l}0.0021^{*} \\
(0.0012)\end{array}$ & & \\
\hline FDI $\times$ ICT Access & & & & & & & & & $\begin{array}{c}0.0001 \\
(0.0007)\end{array}$ & \\
\hline FDI $\times$ ICT Skills & & & & & & & & & & $\begin{array}{c}0.0762 * * * \\
(0.0245)\end{array}$ \\
\hline Constant & $\begin{array}{c}4.4815^{* * *} \\
(0.1991)\end{array}$ & $\begin{array}{c}4.4461 * * * \\
(0.1993)\end{array}$ & $\begin{array}{c}4.0174 * * * \\
(0.2999)\end{array}$ & $\begin{array}{c}4.5683^{* * *} * \\
(0.2005)\end{array}$ & $\begin{array}{c}5.2761 * * * \\
(0.2356)\end{array}$ & $\begin{array}{c}3.8971 * * * \\
(0.2897)\end{array}$ & $\begin{array}{c}4.1882^{* * * *} \\
(0.3055)\end{array}$ & $\begin{array}{c}5.3117 * * * \\
(0.2383)\end{array}$ & $\begin{array}{c}4.5258^{* * *} \\
(0.2037)\end{array}$ & $\begin{array}{c}3.7810 * * * \\
(0.2910)\end{array}$ \\
\hline Observations & 1,680 & 1,680 & 164 & 1,676 & 610 & 941 & 164 & 610 & 1,676 & 941 \\
\hline $\mathrm{R}$-squared & 0.317 & 0.319 & 0.624 & 0.320 & 0.382 & 0.400 & 0.640 & 0.386 & 0.322 & 0.406 \\
\hline Adj R-Sqr & 0.315 & 0.317 & 0.610 & 0.318 & 0.376 & 0.396 & 0.622 & 0.378 & 0.319 & 0.401 \\
\hline
\end{tabular}

Standard errors in parentheses $* * * \mathrm{p}<0.01, * * \mathrm{p}<0.05, * \mathrm{p}<0.1$ 


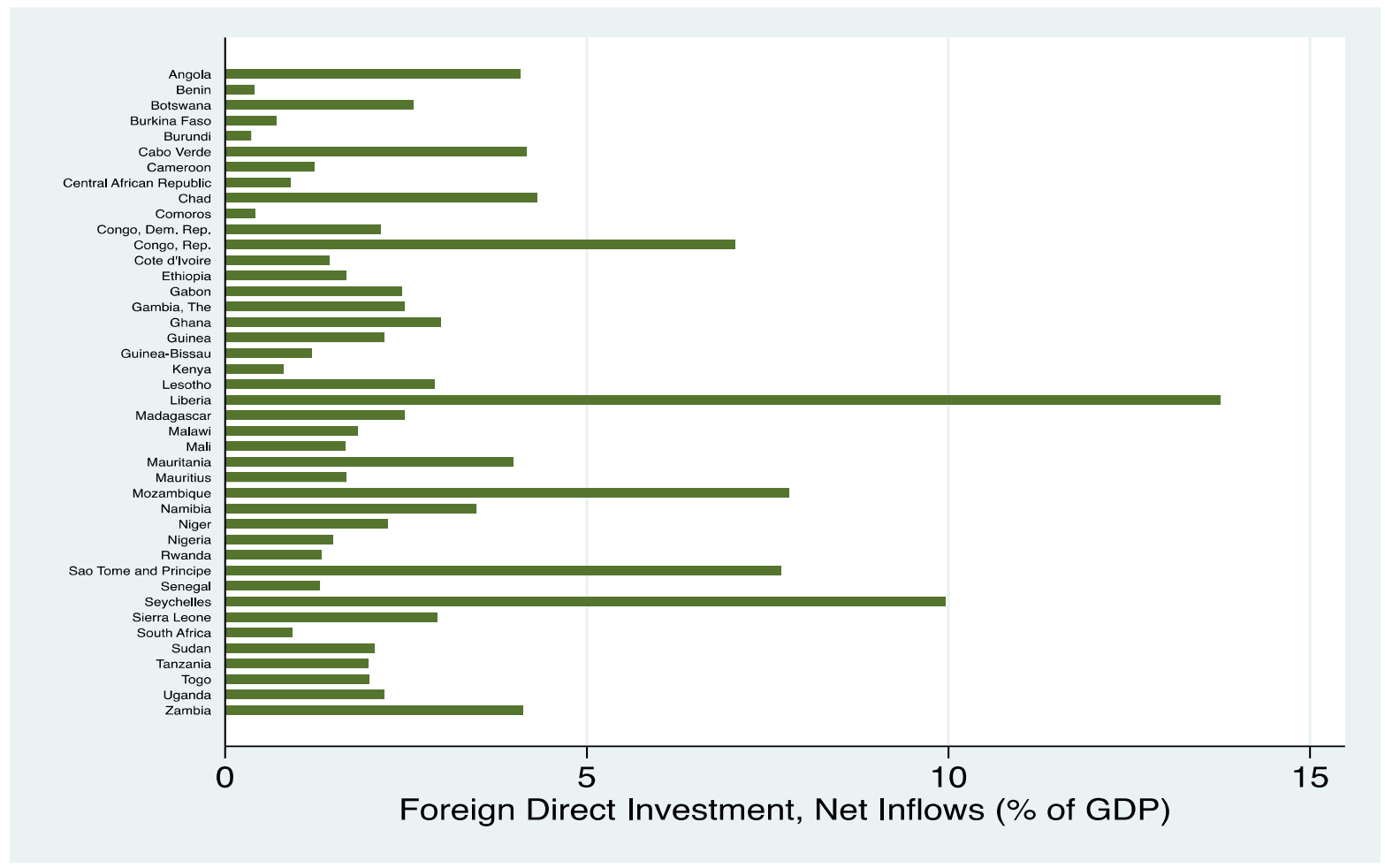

Figure A.1: Average Within-Country FDI InflowIn SSA, 1980 - 2020

- Tech-Hubs, D.R.

- Tech-Hungo,' Benin ,

$$
10
$$

Tech-Hubs, Togo, 14

- Tech-Hubs, Ugansa,

- Tech-Hubs, Rwanda,

10 Tech-Hubs,

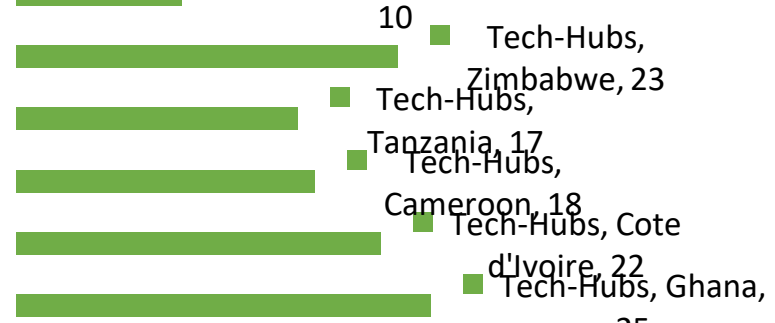

25

- Tech-Hubs, Kenya,

48

Tech-Hubs, South

Tech-Hubs, Nigeria, 85

Figure A.2: Major Tech-Hub Countries In Sub-Saharan Africa

Source: GSM Association Data, 2021 


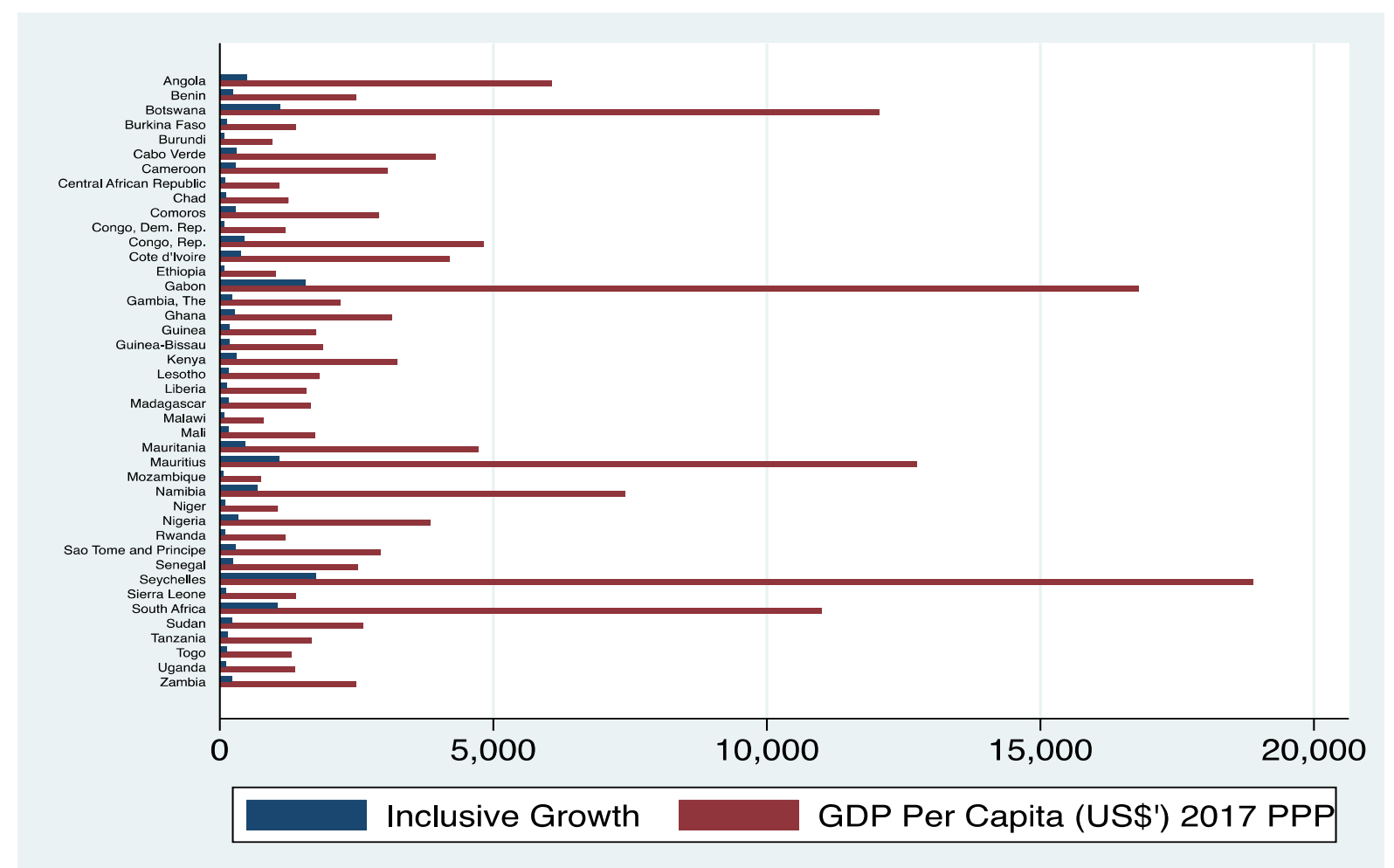

Figure A.3: Average Within Country Inclusive Growth and GDP Per Capita In SSA, 1980 2020 


\section{Supplementary Material}

\section{Measurement of Inclusive Growth by Anand et al. (2013)}

This writeup is reproduced from the original article with permission of the IMF as per the IMF copyright and usage effective January 02, 2020.

To integrate equity and growth in a unified measure, Anand, Mishra and Peiris (2013) proposed a measure of inclusive growth based on a utilitarian social welfare function drawn from consumer choice literature, where inclusive growth depends on two factors: (i) income growth; and (ii) income distribution. Similar to the consumer theory where the indifference curves represent the changes over time in aggregate demand, Anand, Mishra and Peiris (2013) decomposed the income and substitution effect into growth and distributional components. The underlying social welfare function must satisfy two properties to capture these features: (i) it is increasing in its argument (to capture growth dimension) and (ii) it satisfies the transfer property - any transfer of income from a poor person to a richer person reduces the value of the function (to capture distributional dimension).

A measure of inclusiveness is based on the concept of a concentration curve. Following Ali and Son (2007), Anand, Mishra and Peiris (2013) defined a generalized concentration curve, which they called social mobility curve, $S^{c}$, such that:

$$
S^{c} \approx\left(y_{1}, \frac{y_{1}+y_{2}}{2}, \ldots \ldots \ldots, \frac{y_{1}+y_{2}+\cdots+y_{n}}{n}\right)
$$

Where $\mathrm{n}$ is the number of persons in the population with incomes $y_{1}, y_{2}, \ldots \ldots, y_{n}$, where $y_{1}$ is the poorest person and $y_{n}$ is the richest person. This generalized concentration curve is basically a cumulative distribution of a social mobility vector $S \approx\left(y_{1}, y_{2}, \ldots \ldots, y_{n}\right)$ with an underlying function $W=W\left(y_{1}, y_{2}, \ldots \ldots \ldots, y_{n}\right)$ satisfying the two properties mentioned above to capture growth and distribution dimensions. Since $S^{c}$ satisfies the transfer property, a superior income distribution will always have a higher generalized concentration curve. Similarly, since it is increasing in its argument, higher-income will also have a higher generalized concentration curve. As in Ali and Son (2007), the generalized concentration curves can be presented in continuous time to be more amendable to econometric analysis. The population is arranged in the ascending order of their income. Let $\bar{y}_{l}$ is the average income of the bottom iper cent of the population, where $i$ varies from 0 to 100 and $y_{i}$ is the mean income. Anand, Mishra and Peiris (2013) plotted $\overline{y_{l}}$ for different values of $i$ (curve AB in Appendix A below). Curve AB represents a social mobility curve discussed above. Since a 
higher curve implies greater social mobility, growth is inclusive if the social mobility curve moves upward at all points. However, there may be degrees of inclusive growth depending on: (i) how much the curve moves up (growth); and (ii) how the distribution of income changes (equity). This feature of the social mobility curve is the basis of our integrated measure of inclusive growth. Thus, if two generalized concentration curves do not intersect, they could be ranked on social mobility (i.e. inclusiveness of growth). To illustrate the point made above, Appendix A depicts two social mobility curves with the same average income $(\bar{y})$ but different degrees of inclusiveness (i.e. different income distribution). Social mobility curve $(\mathrm{A} 1 \mathrm{~B})$ is more inclusive than the social mobility curve $\mathrm{AB}$, as the average income of the bottom segment of the society is higher.

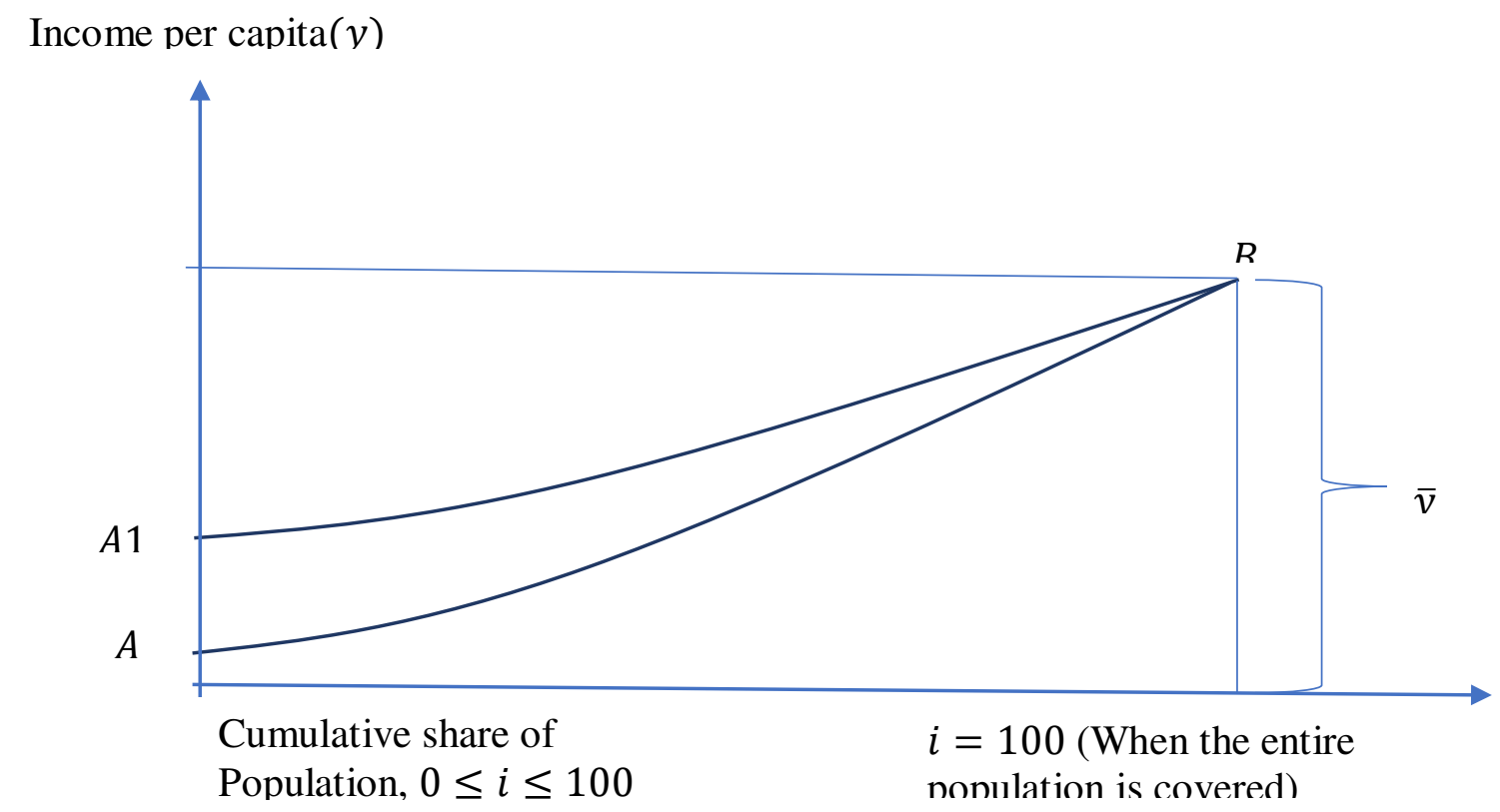

Source: Anand et al. (2013)

To capture the magnitude of the change in income distribution, Anand, Mishra and Peiris (2013) used a simple form of the social mobility function by calculating an index (or social mobility index) from the area under the social mobility curve:

$$
\bar{y}^{*}=\int_{0}^{100} \bar{y}_{l} d i
$$

The greater the $\bar{y}^{*}$, the greater is the income. If the income of everyone in the population is the same (i.e. if income distribution is completely equitable) then $\bar{y}^{*}$ will be equal to $\bar{y}$. If $\bar{y}^{*}$ is lower than $\bar{y}$, it implies that the distribution of income is inequitable. So, the deviation of 
$\bar{y}^{*}$ from $\bar{y}$ is an indication of inequality in income distribution. Ali and Son (2007 use this feature of $\bar{y}^{*}$ and propose an income equity index (IEI) as:

$$
\omega=\frac{\bar{y}^{*}}{\bar{y}}
$$

For a completely equitable society, $\omega=1$. Thus, a higher value of $\omega$ (closer to one) represents higher income equality. Rearranging,

$$
\bar{y}^{*}=\omega * \bar{y}
$$

Inclusive growth requires increasing $\bar{y}^{*}$, which could be achieved by: (i) increasing $\bar{y}$, that is increasing average income through growth; (ii) increasing the equity index of income, $\omega$, through increasing equity; or (iii) a combination of (i) and (ii). Differentiating the above equation:

$$
d \bar{y}^{*}=\omega * d \bar{y}+d \omega * \bar{y}
$$

Where $d \bar{y}^{*}$ is the change in the degree of inclusive growth. Growth is more inclusive if $d \bar{y}^{*}>0$. It also allows us to decompose inclusive growth into income growth and change in equity. The first term is the contribution of an increase in average income (keeping income distribution constant) while the second term is the contribution of changes in the income distribution (keeping the average income unchanged). Inclusive growth depends on the sign and the magnitude of the two terms. 